\title{
Isotope geochemistry and petrogenesis of peralkaline Middle Miocene ignimbrites from central Sonora: relationship with continental break-up and the birth of the Gulf of California
}

\author{
Jesús R. VIDAL SOLANO ${ }^{1,2}$, Henriette LAPIERRE ${ }^{3, \dagger}$, JoAnn M. STOCK ${ }^{4}$, Alain DEMANT ${ }^{2}$, Francisco A. PAZ \\ MORENO $^{1}$, DElPHINE BOSCH ${ }^{5}$, PierRe BRUNET ${ }^{6}$ and ANDREA AMORTEGUI ${ }^{3}$
}

\begin{abstract}
Key-words. - Peralkaline ignimbrites, Middle Miocene, Isotope geochemistry, Gulf of California.
Abstract. - Middle Miocene peralkaline ignimbrites constitute a specific geodynamic marker of the early stage of opening of the Gulf of California, preserved either in central Sonora or the Puertecitos area, in Baja California. Very uniform ages (12-12.5 Ma) obtained on these rocks show that this volcanic episode corresponds to a specific stage in the tectonic evolution of the proto-gulf area. Field observations and slightly different $\mathrm{Sr}$ and $\mathrm{Nd}$ isotopic signatures support eruptions from several small volume magma batches rather than from a large-volume caldera forming event. Isotopic ratios help to constrain the petrogenesis of the peralkaline liquids by fractional crystallization of transitional basalts in a shallow reservoir, with slight contamination by Precambrian upper crustal material. Less differentiated glomeroporphyritic icelandites erupted at about $11 \mathrm{Ma}$, mark an increase in the magma production rate and highlight an easier access to the surface, illustrating an advanced stage in the weakening of the continental crust. The tilting of the Middle Tertiary sequences results from a major change in the tectonic regime, from $\mathrm{E}-\mathrm{W}$ extension giving rise to $\mathrm{N}-\mathrm{S}$ grabens, to NNW-SSE strike-slip motion that can be related to the transfer of Baja California from North America to the Pacific plate. The location of peralkaline volcanism coincides with the southern edge of the Precambrian crust and the southernmost extension of the California slab window at $12.5 \mathrm{Ma}$.
\end{abstract}

Géochimie isotopique et pétrogenèse des ignimbrites hyperalcalines du Miocène moyen du Sonora central : relations avec la déchirure continentale et la naissance du golfe de Californie

\begin{abstract}
Mots-clés. - Ignimbrites hyperalcalines, Miocène moyen, Géochimie isotopique, Golfe de Californie.
Résumé. - Les ignimbrites hyperalcalines du Miocène moyen constituent un excellent marqueur du stade initial de l'ouverture du golfe de Californie. Elles sont préservées aussi bien en Sonora central que sur la marge orientale de la péninsule de Basse Californie, dans la région de Puertecitos. Les âges uniformes obtenus sur ces roches (12.5-12 Ma) montrent que cet épisode volcanique correspond à un stade spécifique de l'évolution du golfe de Californie. Les données de terrain, ainsi que les données isotopiques, indiquent que les ignimbrites correspondent à plusieurs venues de faibles volumes, plutôt qu'à une éruption majeure se terminant par un effondrement en caldera. Les données isotopiques permettent en outre de préciser que les ignimbrites sont le résultat de processus de cristallisation fractionnée à partir de basaltes transitionnels, avec une faible contamination par la croûte supérieure précambrienne. Les laves vitreuses gloméroporphyriques de $11 \mathrm{Ma}$ (islandites) témoignent d'une production magmatique plus importante et d'un accès plus aisé vers la surface, en relation sans doute avec une croûte continentale plus amincie. Le basculement des séquences du Miocène moyen et supérieur témoigne d'un changement majeur du champ de contrainte, depuis une extension E-W à l'origine de grabens N-S, à un système transtensif NNW-SSE qui résulte du transfert de la péninsule de Basse Californie, de la plaque Amérique du Nord à la plaque Pacifique. Le volcanisme hyperalcalin s'est manifesté sur la bordure méridionale du craton nord-américain, à l'aplomb de la terminaison du slab-window de Californie, à 12.5 Ma.
\end{abstract}

\section{INTRODUCTION}

The generation of peralkaline silicic volcanic rocks is a long-standing debated problem in igneous petrology [e.g. Scaillet and Macdonald, 2001; Peccerillo et al., 2003 and references therein]. An origin through fractional crystallization of mildly alkalic to transitional basalts, as exposed in the pioneer works on the Afar rift, Ethiopia [Barberi et al., 1974, 1975; Bizouard et al., 1976, 1980], is a popular model that seems to apply in many cases, either in continental

\footnotetext{
1. Departamento de Geología, Universidad de Sonora, Apdo Postal 847, 83000 Hermosillo, Sonora, Mexique. jrvidal@ciencias.uson.mx

2. Pétrologie magmatique, Université Paul Cézanne (Aix-Marseille 3), CC 441, 13397 Marseille cedex 20, France

3. Laboratoire de Géologie des Chaînes Alpines, UMR 5025, Université Joseph Fourier (Grenoble 1), BP 53, 38041 Grenoble cedex, France.

$\uparrow$ Décédée en Janvier 2006

4. California Institute of Technology, Seismo Lab 252-21, 1200 E. California Blvd., Pasadena CA 91125 USA

5. Laboratoire de Tectonophysique, UMR-CNRS 5568, ISTEEM, Université de Montpellier 2, CC049, 34095 Montpellier cedex 05, France

6. Laboratoire Mécanismes de Transfert en Géologie, UMR 5563, Université Paul Sabatier (Toulouse 2), 31400 Toulouse, France

Manuscrit déposé le 20 février 2007; accepté après modfication le 11 septembre 2007
} 
[e.g. Gasparon et al., 1993; Civetta et al., 1998] or oceanic environments [e.g. Mungall and Martin, 1995]. However, such an origin is difficult to invoke when the volume of felsic rocks is much greater than that of the basalts. In that case, other petrogenetic models such as partial melting of the crust [e.g. Davies and Macdonald, 1987; Macdonald et al., 1987; Lighfoot et al., 1987; Black et al., 1997] or partial melting of mafic precursors followed by fractionation and crustal contamination [e.g. Mahood and Baker, 1986; Mahood et al., 1990; Lowenstern and Mahood, 1991] have been proposed. Furthermore, specific conditions control the generation of oversaturated peralkaline magmas [Bohrson and Reid, 1997; Caricchi et al., 2006]; (1) they are the result of low pressure crystallization in shallow crustal magma reservoirs, as shown by the predominance of alkali feldspar phenocrysts, and (2) these magmas are restricted to extensional tectonic settings in regions characterized by moderate rates of extension [Macdonald, 1974b; Mahood, 1984].

In central Sonora (NW México), a peculiar volcanic episode represented by peralkaline ignimbrites and rhyolites has been defined and dated at about 12.5-12 Ma [Vidal Solano, 2005; Vidal Solano et al., 2005]. The chronology and petrochemical characteristics of the Middle Miocene volcanic sequences have been presented elsewhere [Vidal Solano et al., 2007]. In this paper, we report on the first $\mathrm{Sr}$, $\mathrm{Nd}$ and $\mathrm{Pb}$ isotope data of peralkaline ignimbrites from central Sonora. These results are discussed with the aim of placing constraints on: (1) the genesis of these peralkaline oversaturated volcanics and (2), the timing and conditions of continental break-up and opening of the Gulf of California rift system.

\section{GEOLOGICAL AND PETROLOGICAL BACKGROUND}

Middle Miocene ignimbrites have long been recognized in central Sonora [Morales-Montaño et al., 1990; Paz-Moreno, 1992; Bartolini et al., 1992, 1994; McDowell et al., 1997; Mora-Álvarez and McDowell, 2000] but never considered, until recently [Vidal Solano et al., 2005], as a specific geodynamic marker. Their peralkaline character [Vidal Solano et al., 2005] is defined (1) by a peculiar mineralogical association (fayalite + Fe-rich augite + alkali feldspar phenocrysts and zircon as a common trace mineral) and (2) their major element geochemistry (Al-poor and alkali-rich) that classify them as comendites [Sutherland, 1974; Macdonald, 1974a; Le Maitre, 1989]. Peralkaline ignimbrites are preserved as scattered tilted mesas in a vast area from coastal Sonora to the foot of the Sierra Madre Occidental (fig. 1) and from San Miguel de Horcasitas (29³0'N) to Guaymas $\left(28^{\circ} \mathrm{N}\right)$.

The stratigraphic columns presented in figure 2, constrained by ${ }^{40} \mathrm{Ar} /{ }^{39} \mathrm{Ar}$ age determinations [Vidal Solano et al., 2005, 2007], summarize the volcanic successions observed in central Sonora. Ignimbrites rest mostly on top of poorly-sorted detrital sediments that accumulated in elongated fault-bounded half-graben basins related to Tertiary crustal extension [Gans, 1997; McDowell et al., 1997; Gans et al., 2003]. They correspond to a single cooling unit (up to $50 \mathrm{~m}$ thick), with a black to dark brown vitrophyre commonly present in the lower part, near the contact with gravels and conglomerates that represent the beds of palaeovalleys flooded by the pyroclastic unit. In the surroundings of the small mining town of La Colorada two ignimbritic sheets are present (e.g. Cerro Chapala); yet the absence of any unconformity between them shows that the two pyroclastic units were emplaced in a short time interval. Indeed, all the geochronological data [e.g. Bartolini et al., 1994; McDowell et al., 1997; Oskin, 2002; Oskin and Stock, 2003a; Vidal Solano et al., 2005, 2007] converge to show that peralkaline ignimbrites in coastal and central Sonora were erupted at 12.5-12 Ma. Rhyolitic domes with similar peralkaline characteristics are exposed in the southern part of the study area. The $12.1 \mathrm{Ma}$ age obtained on a peralkaline rhyolite lava from Cerro Sarpullido (fig. 2) manifests that rhyolite and ignimbrite are part of the same volcanic episode. Moreover, granophyric fragments that can be considered as the solidified intrusive equivalent of the lavas [Lowenstern et al., 1997], observed in the rhyolites attest for the presence of subvolcanic bodies. In this southern area, volcanic products exhibit fragmentation and yellow quenched margins that evidence contact with water [Stroncik and Schmincke, 2002; Vidal Solano, 2005]. This shows that extension was clearly underway in central Sonora during the Middle Miocene and that lakes could have flooded parts of the grabens.

In many places southeast of Hermosillo (e.g. Sierra Lista Blanca (fig. 3a) or Sierra San Antonio) ignimbrites or rhyolites are capped by black glomeroporphyritic lava flows (fig. $3 \mathrm{~b}$ ), with dominant phenocrysts of plagioclase (An42-30), augite (Wo38En35Fs27), pigeonite (Wo8.5En45.5Fs46) and $\mathrm{Fe}-\mathrm{Ti}$ oxides. These crystals are set in a glassy groundmass with perlitic fractures [Vidal Solano, 2005]. At Cerro Chivato (fig. 2), one of these lava flows was dated at $10.9 \pm$ $0.4 \mathrm{Ma}$ [Vidal Solano et al., 2007]. This Ar/Ar age is concordant with previously published K/Ar dates at Sierra Lista Blanca [Morales-Montaño et al., 1990; McDowell et al., 1997], indicating that the emplacement of the intermediate lavas was contemporaneous. A major extensional event occurred after this volcanic episode because the whole Middle to Upper Miocene Sierra Lista Blanca sequence is tilted toward the west (fig. 3b). This tectonic episode was furthermore responsible for erosion and massive deposition of detrital alluvial fan material during the latest Miocene and Pliocene.

Middle Miocene basalts are scarce in central Sonora. A small outcrop of mafic rocks is observed at the base of Cerro Las Cuevitas, near Hermosillo [Vidal Solano et al., 2005]. The $12.54 \pm 0.84 \mathrm{Ma}$ Ar/Ar age obtained on this basalt confirms it is penecontemporaneous with the peralkaline acidic sequence [Vidal Solano et al., 2005]. Flat lying basaltic mesas overlie the peralkaline ignimbrites west of Santa Rosalía (fig. 1). These basalts include olivine, clinopyroxene and plagioclase megacrysts, a discriminant feature for Plio-Quaternary alkali volcanism in central Sonora [Paz-Moreno, 1992; Paz-Moreno et al., 2003]. In short, as a result of its mode of emplacement, the Middle Miocene peralkaline ignimbrite event is a good stratigraphic marker for the tectonic evolution of the region. Moreover, the eruption of large volumes of intermediate transitional magmas after the ignimbrite outburst, helps to constrain the petrogenetic and tectonic processes that precede the Gulf of California opening. 


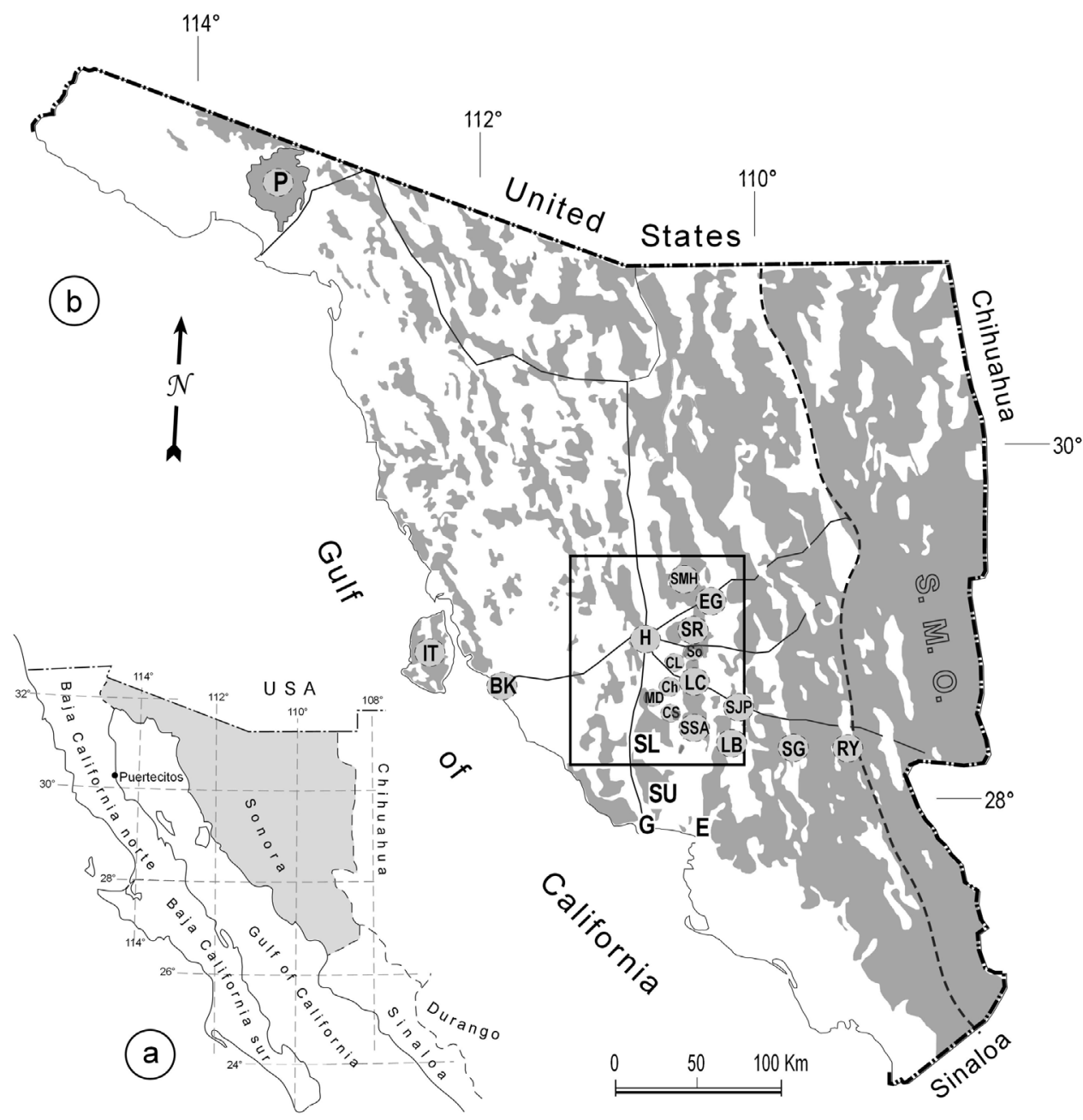

FIG. 1. - (a) Geographic framework of the Sonora State. (b) Basin and range morphology in the State of Sonora, and location of the study area. Basins are in white, ranges in grey. Main outcrops of peralkaline ignimbrites : BK, Bahía de Kino; Ch, Cerro Chapala; CL, Cerro La Legua; CS, Cerro Sarpullido; EG, El Gavilán; IT, Isla Tiburón; LB, Sierra Lista Blanca; MD, Mina Divisadero; P, Pinacate; RY, Río Yaqui; SG, Suaqui Grande; SJP, San José de Pima; SL, Sierra Libre; SMH, San Miguel de Horcasitas; So, Cerro La Sonora; SR, Santa Rosalía; SSA, Sierra San Antonio; SU, Sierra Santa Ursula. Populated places : E, Empalme; G, Guaymas; H, Hermosillo; LC, La Colorada. For a more precise location of the studied samples refer to the maps in Vidal Solano [2005]. The stippled line marks the western limit of the Sierra Madre Occidental (S.M.O.) ignimbrite plateau.

FIG. 1. - (a) Cadre géographique de l'Etat du Sonora. (b) Morphologie en «Basin and range » de l'Etat du Sonora et localisation du secteur d'étude. Les bassins sont en blanc et les reliefs en grisé. Principaux affleurements d'ignimbrites hyperalcalines. Pour une localisation plus précise des échantillons étudiés voir les cartes figurant dans Vidal Solano [2005]. La ligne en pointillés, marque la limite occidentale du plateau de la Sierra Madre Occidental (S.M.O.).

\section{GEOCHEMISTRY}

\section{Analytical procedures}

Rock samples were first ground in a steel jaw crusher and then finely powdered in an agate grinder. Major and trace elements were obtained by inductively coupled plasma-atomic emission spectrometry (ICP-AES) at CEREGE (Université Paul Cézanne, Aix-Marseille 3), except for $\mathrm{Na}, \mathrm{K}$ and $\mathrm{Rb}$, which were determined by flame atomic absorption spectrophotometry, and $\mathrm{Fe} 2+$ by titration. Rare earth elements (REE) and additional trace elements were analysed by inductively coupled plasma-mass spectrometry (ICP-MS) in LGCA at the Université Joseph Fourier Grenoble 1, following the procedure of Barrat et al. [1996] or the Centre de Recherches Pétrographiques et Géochimiques (CRPG) at Nancy. Analytical errors are 1-3\% for major elements and less than $3 \%$ for trace elements.
$\mathrm{Sr}$ (static acquisition) and $\mathrm{Nd}$ (dynamic acquisition) isotopic ratios were measured on nine samples at the Université Paul Sabatier (Toulouse) on a Finnigan MAT261 multicollector mass spectrometer using the analytical procedures of Lapierre et al. [1997]. Results on La Jolla Nd standard yielded ${ }^{143} \mathrm{Nd} /{ }^{144} \mathrm{Nd}=0.511850 \pm 8$ (mean on 39 runs), corresponding to an external reproducibility of 0.00001 . Results on NBS $987 \mathrm{Sr}$ standard yielded ${ }^{87} \mathrm{Sr} /{ }^{86} \mathrm{Sr}$ $=0.710250$ (mean on 200 runs). The within-run precision (2 $\sigma$ absolute) for ${ }^{87} \mathrm{Sr} /{ }^{86} \mathrm{Sr}$ was $0.000008-0.000015$ and 0.000007-0.000011 for ${ }^{143} \mathrm{Nd} /{ }^{144} \mathrm{Nd}$.

For lead separation, six powdered samples were weighed to obtain approximately 100 to $200 \mathrm{ng}$ of lead. The chemical separation of $\mathrm{Pb}$ was carried out following the procedure modified from Manhès et al. [1980]. Total Pb blanks are less than $65 \mathrm{pg}$ for a $100 \mathrm{mg}$ sample. Lead isotopes were analysed on a VG Plasma 54 multicollector inductively coupled plasma-mass spectrometer (MC-ICP-MS) at 

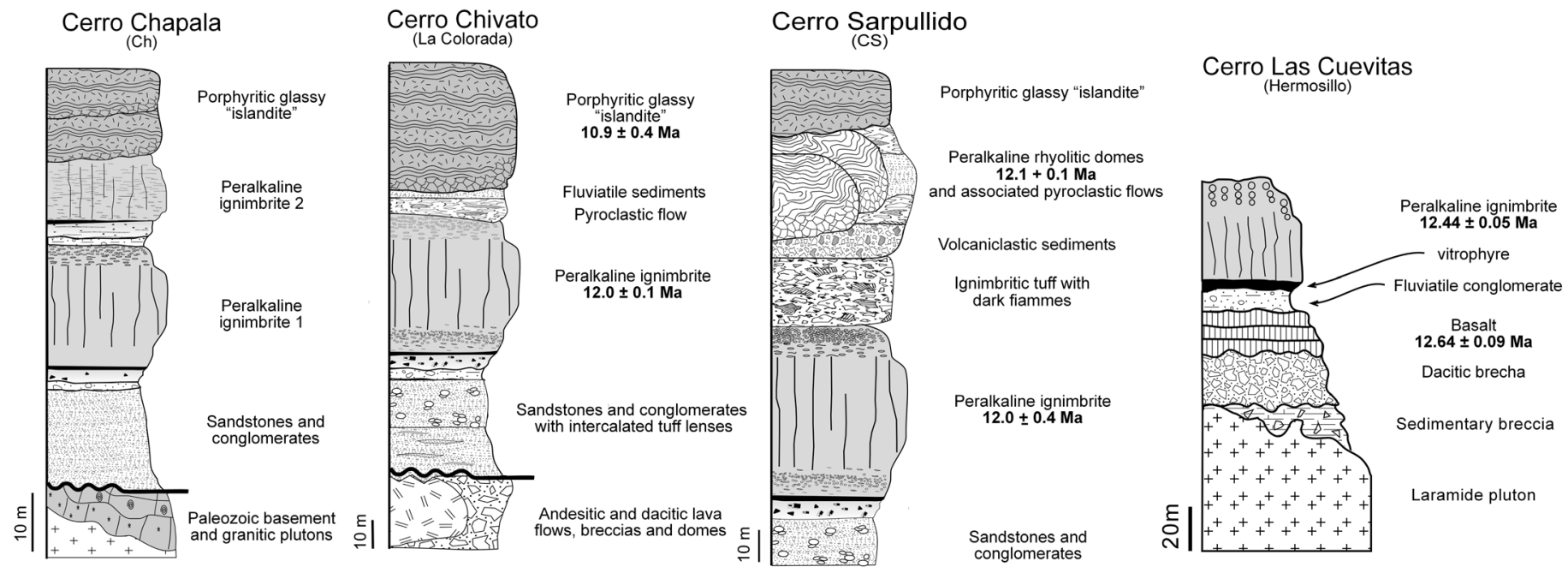

FIG. 2. - Representative stratigraphic columns showing the age and relationship of Middle Miocene volcanic sequences in central Sonora. Cerro Chapala and Cerro Chivato are located just southwest of La Colorada (fig. 1).

FIG. 2. - Colonnes stratigraphiques et âge des principales séquences volcaniques du Miocène moyen du Sonora central. Les Cerros Chapala et Chivato sont situés immédiatement au sud-ouest de La Colorada (fig. 1).

the Ecole Normale Supérieure de Lyon. Lead isotope compositions were measured using the Tl normalization method described by White et al. [2000]. For Pb isotope analysis, samples were bracketed between NIST 981 standards and calculated with respect to the value reported for this standard by Todt et al. [1996]. This technique yields internal precision of ca. $50 \mathrm{ppm}(2 \sigma)$ and an external reproducibility of ca. $150 \mathrm{ppm}(2 \sigma)$ for ${ }^{206} \mathrm{~Pb} /{ }^{204} \mathrm{~Pb}$ ratios determined on 20 NIST standards. Because corrections for recent volcanic rocks are negligible, initial ratios of the isotopic data have not been calculated.

\section{Sample classification and trace element geochemistry}

Twenty five samples of the Middle Miocene volcanic sequences from central Sonora have been analysed for major and trace elements. Thirteen representative analyses are reported in table I. Previously published data from the Hermosillo region [Vidal Solano et al., 2005] are also used for the discussion of the geochemical signature.

Basalts crop out mostly at Cerro Las Cuevitas near Hermosillo. They have a transitional character: high $\mathrm{TiO}_{2}$ (> $2.5 \mathrm{wt} \%$ ), low $\mathrm{SiO}_{2}$ and $\mathrm{Al}_{2} \mathrm{O}_{3}$, and little nepheline in the norm, are characteristic of alkaline lavas, while high total iron $(>13 \mathrm{wt} \%)$ is more akin to tholeiitic series.

The porphyritic glassy lavas (JR03-1, JR 04-49 \& JR $04-59 \mathrm{~b}$, tabl. I) that rest on the peralkaline ignimbrites have intermediate silica content $(60-65 \mathrm{wt} \%)$ and low alumina (13-14 wt\%). Based on the total alkalis silica (TAS) classification diagram [Le Bas et al., 1986], one of these samples is a high-silica andesite, whereas the others plot in the trachyte field (fig. 4). Nonetheless, high FeOt (5-13 wt\%) and $\mathrm{FeOt} / \mathrm{MgO}$ ratios characterize intermediate lavas of the tholeiitic series (icelandites) [Vidal Solano et al., 2006].

Middle Miocene ignimbrites and rhyolites have high silica contents $(\sim 72-74 \mathrm{wt} \%)$, low alumina $(\sim 12 \mathrm{wt} \%)$ and highly variable total alkalis (tabl. I, fig. 4). The mobility of the alkalis, particularly $\mathrm{Na}$, has a critical effect on the absence of acmite in the norm of the majority of the ignimbrite samples. Low contents in alumina and iron contribute furthermore to the classification of these oversaturated rocks as comendites [Sutherland, 1974; Macdonald, 1974a; Le Maitre, 1989].

Major and trace element compositions of the Middle Miocene lavas from central Sonora have been discussed in a companion paper [Vidal Solano et al., 2007]. We will therefore only briefly summarize here their main characteristics. The rare-earth element (REE) patterns (fig. 5) are very similar for all the peralkaline ignimbrites (fifteen samples). They are enriched in light REE $\left([\mathrm{La} / \mathrm{Yb}]_{\mathrm{N}}=6.8\right.$ to 8.3$)$, present relatively flat but irregular heavy REE (HREE) patterns, and a strong depletion in Eu. Evidence for extensive feldspar fractionation involved in the generation of these liquids also comes from low $\mathrm{Sr}$ abundances (tabl. I). REE patterns of icelandites are slightly less enriched $\left([\mathrm{La} / \mathrm{Yb}]_{\mathrm{N}} \sim 6.5\right)$, and they display a smaller negative anomaly in Eu. On the MORB-normalized spidergram [Pearce, 1983], the Hermosillo basalt is slightly enriched in the less incompatible trace elements compare to N-MORB, and presents a positive anomaly in $\mathrm{Ba}$ (fig. 6). Patterns of icelandite and peralkaline ignimbrites are subparallel to that of the basalt, from $\mathrm{Nb}$ to $\mathrm{Yb}$, but strongly enriched in $\mathrm{K}, \mathrm{Rb}$, Th, and depleted in Sr. Increasing negative anomalies in $\mathrm{Ti}, \mathrm{P}$, and $\mathrm{Ba}$ are clearly related to differentiation involving $\mathrm{Fe}$ - $\mathrm{Ti}$ oxides, apatite and feldspar. The behaviour of the trace elements suggests therefore some kind of genetic link between the transitional basalt, the porphyritic glassy lavas (icelandites), and the peralkaline oversaturated ignimbrites.

Petrochemical similarities exist between the Middle Miocene volcanic sequences from central Sonora and the Quaternary comenditic rhyolites from Sierra La Primavera, Jalisco (figs. 4 and 5). By contrast, petrology and isotopic signatures of felsic rocks (fig. 7) clearly differ from those of the Miocene sequences from Sierra Santa Ursula [Mora-Álvarez and McDowell, 2000], located at the western edge of the Empalme graben (fig. 1). 
TABLE I. - Representative chemical analyses of Middle Miocene volcanic rocks from central Sonora. Major elements are in weight \%, trace elements in ppm. Rock types: B = basalt; I = icelandite; Ign = ignimbrite; R = rhyolite. Localities: Hllo = Hermosillo; CCha = Cerro Chapala; SSA = Sierra San Antonio; MD = Mina Divisadero; CS = Cerro Sarpullido; CL = Cerro La Legua; CLS = Cerro La Sonora; SMH = San Miguel de Horcasitas; SJP = San José de Pimas. For the ignimbrites, vitrophyric facies have been sampled. A.I. = Agpaitic Index [molar $\mathrm{Al} /(\mathrm{Na}+\mathrm{K})]$.

TABL. I. - Analyses chimiques représentatives (majeurs et traces) de roches volcaniques du Miocène moyen du Sonora central. Éléments majeurs en poids \%, éléments traces en ppm. Les échantillons d'ignimbrites ont été prélevés dans les niveaux vitrophyriques. A.I. $=$ indice d'agpaicité [Al/(Na+K)].

\begin{tabular}{|c|c|c|c|c|c|c|c|c|c|c|c|c|c|}
\hline $\begin{array}{l}\text { Sample N }{ }^{\circ \circ} \\
\text { Rock-type } \\
\text { Locality }\end{array}$ & $\begin{array}{l}\mathrm{H} 96-2^{\circ \circ} \\
\text { B } \\
\text { Hllo }\end{array}$ & $\begin{array}{c}\text { JR03-1* } \\
\text { I } \\
\text { CCha }\end{array}$ & $\begin{array}{c}\text { JR04-49 } \\
1 \\
\text { SSA }\end{array}$ & $\begin{array}{c}\text { JR04-59B } \\
\quad \text { I } \\
\text { SSA }\end{array}$ & $\begin{array}{l}\text { JR03-9* } \\
\text { Ign } \\
\text { MD }\end{array}$ & $\begin{array}{l}\text { JR04-40 } \\
\text { Ign } \\
\text { MD }\end{array}$ & $\begin{array}{l}\text { JR04-30A } \\
\operatorname{lgn} \\
\text { CS }\end{array}$ & $\begin{array}{c}\text { JR04-35A } \\
\text { R } \\
\text { CS }\end{array}$ & $\begin{array}{l}\text { JRO2-19* } \\
\text { Ign } \\
\text { CCha }\end{array}$ & $\begin{array}{l}\text { JR03-7 } \\
\text { Ign } \\
\text { CL }\end{array}$ & $\begin{array}{l}\text { JR02-21A } \\
\text { Ign } \\
\text { CLS }\end{array}$ & $\begin{array}{l}\text { JR02-71C } \\
\text { Ign } \\
\text { SMH }\end{array}$ & $\begin{array}{c}\text { JR04-12B } \\
\text { Ign } \\
\text { SJP }\end{array}$ \\
\hline $\mathrm{SiO}_{2}(\mathrm{wt} \%)$ & 47.69 & 61.41 & 65.96 & 64.70 & 73.60 & 72.63 & 72.65 & 74.18 & 74.31 & 73.57 & 72.67 & 71.91 & 72.96 \\
\hline $\mathrm{TiO}_{2}$ & 2.51 & 0.85 & 0.86 & 0.86 & 0.17 & 0.13 & 0.13 & 0.14 & 0.24 & 0.12 & 0.12 & 0.11 & 0.13 \\
\hline $\mathrm{Al}_{2} \mathrm{O}_{3}$ & 15.37 & 13.34 & 13.99 & 13.97 & 11.89 & 12.72 & 12.22 & 11.75 & 12.89 & 12.24 & 12.42 & 12.18 & 12.42 \\
\hline $\mathrm{Fe}_{2} \mathrm{O}_{3}$ & 7.36 & 9.97 & 4.91 & 5.03 & 0.80 & 1.77 & 1.85 & 1.80 & 2.09 & 1.75 & 1.75 & 1.74 & 1.82 \\
\hline $\mathrm{FeO}$ & 5.90 & 2.90 & $\ldots$ & $\ldots$ & 0.85 & 0.23 & 0.47 & 0.63 & 0.39 & $\ldots$ & $\ldots$ & $\ldots-$ & 0.37 \\
\hline $\mathrm{MnO}$ & 0.21 & 0.11 & 0.09 & 0.09 & 0.04 & 0.03 & 0.04 & 0.03 & 0.07 & 0.02 & 0.04 & 0.03 & 0.03 \\
\hline $\mathrm{MgO}$ & 5.94 & 1.00 & 1.01 & 1.07 & 0.09 & $<$ L.D. & $<$ L.D. & $<$ L.D. & 0.15 & 0.13 & 0.08 & 0.10 & $<$ L.D. \\
\hline $\mathrm{CaO}$ & 8.60 & 2.22 & 2.77 & 2.78 & 0.55 & 0.50 & 0.76 & 0.58 & 0.51 & 0.67 & 0.65 & 0.48 & 0.57 \\
\hline $\mathrm{Na}_{2} \mathrm{O}$ & 3.34 & 3.12 & 3.80 & 3.76 & 3.81 & 3.49 & 4.09 & 3.12 & 3.85 & 3.87 & 4.06 & 3.25 & 3.07 \\
\hline $\mathrm{K}_{2} \mathrm{O}$ & 0.70 & 3.48 & 4.12 & 3.78 & 3.83 & 5.19 & 3.93 & 5.08 & 5.00 & 4.97 & 4.50 & 5.22 & 5.78 \\
\hline $\mathrm{P}_{2} \mathrm{O}_{5}$ & 0.49 & 0.22 & 0.24 & 0.24 & 0.03 & <L.D. & $<$ L.D. & $<$ L.D. & 0.08 & 0.17 & $<$ L.D. & $<$ L.D. & $<$ L.D. \\
\hline $\mathrm{H}_{2} \mathrm{O}+$ & 0.41 & 1.85 & $\ldots$ & $\ldots$ & 3.35 & $\ldots$ & $\ldots$ & $\ldots$ & 0.15 & $\ldots$ & $\ldots$ & $\ldots$ & $-\ldots$ \\
\hline $\mathrm{H}_{2} \mathrm{O}-$ & 0.27 & 0.12 & $\ldots$ & $\ldots$ & 0.04 & 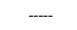 & 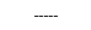 &.- & 0.32 & -- & - &.- &.- \\
\hline LOI & & - & 2.10 & 3.00 & - & 3.52 & 4.15 & 3.42 & - & 1.08 & 3.79 & 3.67 & 3.19 \\
\hline Total & 98.79 & 100.59 & 99.86 & 99.27 & 99.05 & 100.21 & 100.28 & 100.72 & 100.05 & 98.58 & 100.07 & 98.68 & 100.35 \\
\hline A.I. & & & & & 0.88 & 0.89 & 0.90 & 0.91 & 0.91 & 0.96 & 0.93 & 0.90 & 0.91 \\
\hline $\mathrm{Rb}(\mathrm{ppm})$ & 14.0 & 136.3 & 134.0 & 129.4 & 178.0 & 171.0 & 203.0 & 188.0 & 148.0 & 176.9 & 190.5 & 180.3 & 166.0 \\
\hline $\mathrm{Sr}$ & 482.0 & 187.4 & 195.0 & 211.2 & 13.8 & 11.4 & 42.2 & 10.0 & 31.1 & 23.5 & 13.0 & 11.2 & 10.2 \\
\hline $\mathrm{Ba}$ & 356.0 & 1116.5 & 1059.7 & 1033.0 & 48.1 & 36.0 & 44.6 & 170.0 & 451.6 & 60.3 & 36.0 & 40.1 & 61.5 \\
\hline $\mathrm{Zr}$ & 248.0 & 428.6 & 445.0 & 430.7 & 317.0 & 314.0 & 321.0 & 272.0 & 499.2 & 297.5 & 347.3 & 294.7 & 348.0 \\
\hline Y & 40.0 & 50.6 & 55.9 & 46.7 & 53.1 & 54.5 & 52.9 & 58.4 & 50.9 & 49.1 & 52.2 & 49.0 & 54.5 \\
\hline $\mathrm{Nb}$ & 21.0 & 19.43 & 19.71 & 15.35 & 23.70 & 23.20 & 23.30 & 22.40 & 22.17 & 20.26 & 21.59 & 20.70 & 23.80 \\
\hline Cs & 0.2 & 3.99 & 3.66 & 3.88 & 6.58 & 6.81 & 8.74 & 6.76 & 2.86 & 3.01 & 5.80 & 5.05 & 5.95 \\
\hline Th & 1.00 & 13.45 & 13.46 & 12.53 & 18.90 & 19.30 & 18.10 & 20.80 & 16.72 & 18.99 & 18.56 & 18.87 & 19.50 \\
\hline $\mathrm{Ta}$ & 0.50 & 1.38 & 1.34 & 1.38 & 1.80 & 1.81 & 1.75 & 1.85 & 1.66 & 1.93 & 1.95 & 1.91 & 1.83 \\
\hline u & 0.50 & 4.16 & 4.22 & 3.99 & 5.74 & 5.69 & 5.48 & 7.33 & 4.62 & 5.33 & 5.81 & 5.79 & 5.68 \\
\hline $\mathrm{Pb}$ & 5.00 & 17.79 & 17.25 & 17.00 & 26.80 & 26.80 & 24.10 & 25.90 & 54.33 & 25.26 & 30.07 & 33.41 & 25.00 \\
\hline $\mathrm{Hf}$ & 7.00 & 9.64 & 10.43 & 9.59 & 9.52 & 9.47 & 9.63 & 8.51 & 11.28 & 9.34 & 10.09 & 9.17 & 10.40 \\
\hline La & 24.5 & 42.86 & 42.49 & 41.75 & 56.90 & 58.40 & 55.20 & 55.30 & 47.57 & 57.87 & 58.80 & 57.06 & 57.70 \\
\hline $\mathrm{Ce}$ & 55.5 & 96.01 & 92.47 & 88.15 & 118.00 & 122.00 & 117.00 & 119.00 & 105.06 & 116.60 & 121.60 & 117.90 & 126.00 \\
\hline $\operatorname{Pr}$ & 7.4 & 11.42 & 11.34 & 10.88 & 13.70 & 14.40 & 14.00 & 14.40 & 12.15 & 14.04 & 14.24 & 13.70 & 14.20 \\
\hline $\mathrm{Nd}$ & 31.5 & 44.82 & 45.03 & 42.15 & 50.20 & 51.90 & 51.10 & 54.00 & 46.06 & 51.51 & 52.36 & 49.97 & 52.20 \\
\hline $\mathrm{Sm}$ & 7.5 & 9.54 & 10.00 & 9.01 & 9.74 & 10.50 & 9.73 & 10.90 & 9.17 & 10.25 & 10.34 & 9.94 & 10.50 \\
\hline Eu & 2.3 & 1.83 & 1.91 & 1.78 & 0.12 & 0.13 & 0.14 & 0.55 & 0.54 & 0.13 & 0.12 & 0.10 & 0.12 \\
\hline $\mathrm{Gd}$ & 7.9 & 8.28 & 8.73 & 8.21 & 8.47 & 9.22 & 8.62 & 9.32 & 8.53 & 8.73 & 8.99 & 8.50 & 8.74 \\
\hline $\mathrm{Tb}$ & 1.4 & 1.37 & 1.49 & 1.31 & 1.43 & 1.54 & 1.45 & 1.63 & 1.40 & 1.44 & 1.47 & 1.40 & 1.51 \\
\hline Dy & 6.6 & 8.57 & 8.86 & 7.99 & 8.68 & 9.17 & 8.42 & 9.93 & 8.16 & 8.63 & 8.87 & 8.42 & 9.04 \\
\hline Ho & 1.4 & 1.78 & 1.83 & 1.56 & 1.83 & 1.91 & 1.84 & 2.03 & 1.73 & 1.71 & 1.74 & 1.67 & 1.91 \\
\hline $\mathrm{Er}$ & 3.8 & 5.10 & 5.21 & 4.56 & 5.41 & 5.47 & 5.20 & 5.89 & 5.08 & 4.96 & 5.04 & 4.89 & 5.55 \\
\hline $\mathrm{Yb}$ & 3.9 & 4.73 & 5.03 & 4.64 & 5.12 & 5.24 & 5.03 & 5.70 & 4.99 & 5.08 & 5.39 & 5.06 & 5.27 \\
\hline Lu & 0.6 & 0.78 & 0.80 & 0.72 & 0.78 & 0.80 & 0.77 & 0.87 & 0.71 & 0.79 & 0.80 & 0.77 & 0.82 \\
\hline
\end{tabular}

\section{$\mathrm{Sr}$, Nd and $\mathrm{Pb}$ isotopic data}

$\mathrm{Sr}, \mathrm{Nd}$ and $\mathrm{Pb}$ radiogenic isotope data for samples from central Sonora are listed in table II. Middle Miocene rocks display a large degree of isotopic heterogeneity on the ${ }^{143} \mathrm{Nd} /{ }^{144} \mathrm{Nd} v s{ }^{87} \mathrm{Sr} /{ }^{86} \mathrm{Sr}$ plot (fig. 7). Other data included in this plot will be discussed subsequently. Hermosillo basalt has the lowest $\mathrm{Sr}(0.7045)$ and the highest $\mathrm{Nd}$ ratio (0.51279). The porphyritic glassy icelandite from Sierra Lista Blanca has slightly higher $\mathrm{Sr}(0.7054)$ and lower $\mathrm{Nd}$ $(0.51265)$. The five peralkaline ignimbrite samples display a large range of ${ }^{87} \mathrm{Sr} /{ }^{86} \mathrm{Sr}$ ratios $(0.7067$ to 0.7187$)$, but a relatively limited variation in ${ }^{143} \mathrm{Nd} /{ }^{144} \mathrm{Nd}(0.51265-0.51270)$. Isotopic ratios for Sarpullido rhyolite are in the same range as those of the ignimbrites (tabl. II). A biotite ignimbrite sample from Mina Divisadero, lying below a peralkaline ignimbritic unit [see Vidal Solano, 2005], has low Nd and high $\mathrm{Sr}$ ratios (tabl. II); it plots in the field of the Sierra Madre Occidental (SMO) ignimbrites.

Lead isotopic compositions were determined on five samples. Ignimbrite, rhyolite and icelandite samples display very little variations in ${ }^{208} \mathrm{~Pb} /{ }^{204} \mathrm{~Pb},{ }^{207} \mathrm{~Pb} /{ }^{204} \mathrm{~Pb}$ and ${ }^{206} \mathrm{~Pb} /{ }^{204} \mathrm{~Pb}$ (tabl. II), forming a tight cluster on lead isotope plots (fig. 8). Hermosillo basalt has the least radiogenic concentrations in $\mathrm{Pb}$. All these data plot above the northern hemisphere reference line (NHRL) of Zindler and Hart [1986] on a ${ }^{207} \mathrm{~Pb} /{ }^{204} \mathrm{~Pb}$ versus ${ }^{206} \mathrm{~Pb} /{ }^{204} \mathrm{~Pb}$ plot, but very close to the NHRL on a ${ }^{208} \mathrm{~Pb} /{ }^{204} \mathrm{~Pb}$ versus ${ }^{206} \mathrm{~Pb} /{ }^{204} \mathrm{~Pb}$ plot.
TABLE II. - Isotopic compositions of Middle Miocene volcanic rocks from central Sonora. Same abbreviations as in table I. T Biot $=$ biotite tuff. TABL. II. - Compositions isotopiques de roches volcaniques du Miocène moyen du Sonora central. Mêmes abréviations que pour la table I. T Biot = tuf à biotite.

\begin{tabular}{lccccccccc}
\hline Sample & Rock-type & Locality & ${ }^{143} \mathrm{Nd} /{ }^{144} \mathrm{Nd}$ & \pm & ${ }^{87} \mathrm{Sr} /{ }^{86} \mathrm{Sr}$ & \pm & ${ }^{206} \mathrm{~Pb} /{ }^{204} \mathrm{~Pb}$ & ${ }^{207} \mathrm{~Pb} /{ }^{204} \mathrm{~Pb}$ & ${ }^{208} \mathrm{~Pb} /{ }^{204} \mathrm{~Pb}$ \\
\hline JR03-1 & I & CCha & 0.512654 & 14 & 0.705414 & 8 & 19.016 & 15.630 & 38.714 \\
JR04-30A & Ign & CS & 0.512651 & 14 & 0.709598 & 16 & 19.041 & 15.634 & 38.747 \\
JR04-35A & R & CS & 0.512592 & 6 & 0.714584 & 26 & 19.063 & 15.631 & 38.743 \\
JR04-39 & T Biot & MD & 0.512520 & 6 & 0.707885 & 11 & & & \\
H3-94 & Ign & Hllo & 0.512671 & 6 & 0.714229 & 8 & 19.026 & 15.620 & 38.702 \\
H96-1 & B & Hllo & 0.512798 & 6 & 0.704499 & 2 & 18.808 & 15.584 & 38.419 \\
JR02-71C & Ign & SMH & 0.512703 & 5 & 0.718700 & 12 & & & \\
JR02-21A & Ign & CLS & 0.512696 & 5 & 0.716566 & 11 & & & \\
JR02-19 & Ign & CCha & 0.512681 & 8 & 0.706767 & 12 & & & \\
\hline
\end{tabular}

\section{DISCUSSION}

\section{Petrogenetic processes and mantle source}

Nearly constant $\mathrm{Nd}$ isotope values but highly variable $\mathrm{Sr}$ isotopic ratios in the ignimbrites indicate that the opening of the $\mathrm{Rb}-\mathrm{Sr}$ system occurred in an upper crustal reservoir. Moreover, as seen with other Miocene peralkaline outcrops in North America [Scott et al., 1995; Edwards and Russell, 2000; Miller et al., 2000], isotopic ratios give also information on the nature of the mantle source. Peralkaline ignimbrites from central Sonora have, as a whole, relatively high ${ }^{87} \mathrm{Sr} /{ }^{86} \mathrm{Sr}$ ratios; they define on the ${ }^{143} \mathrm{Nd} /{ }^{144} \mathrm{Nd} v s{ }^{87} \mathrm{Sr} /{ }^{86} \mathrm{Sr}$ 

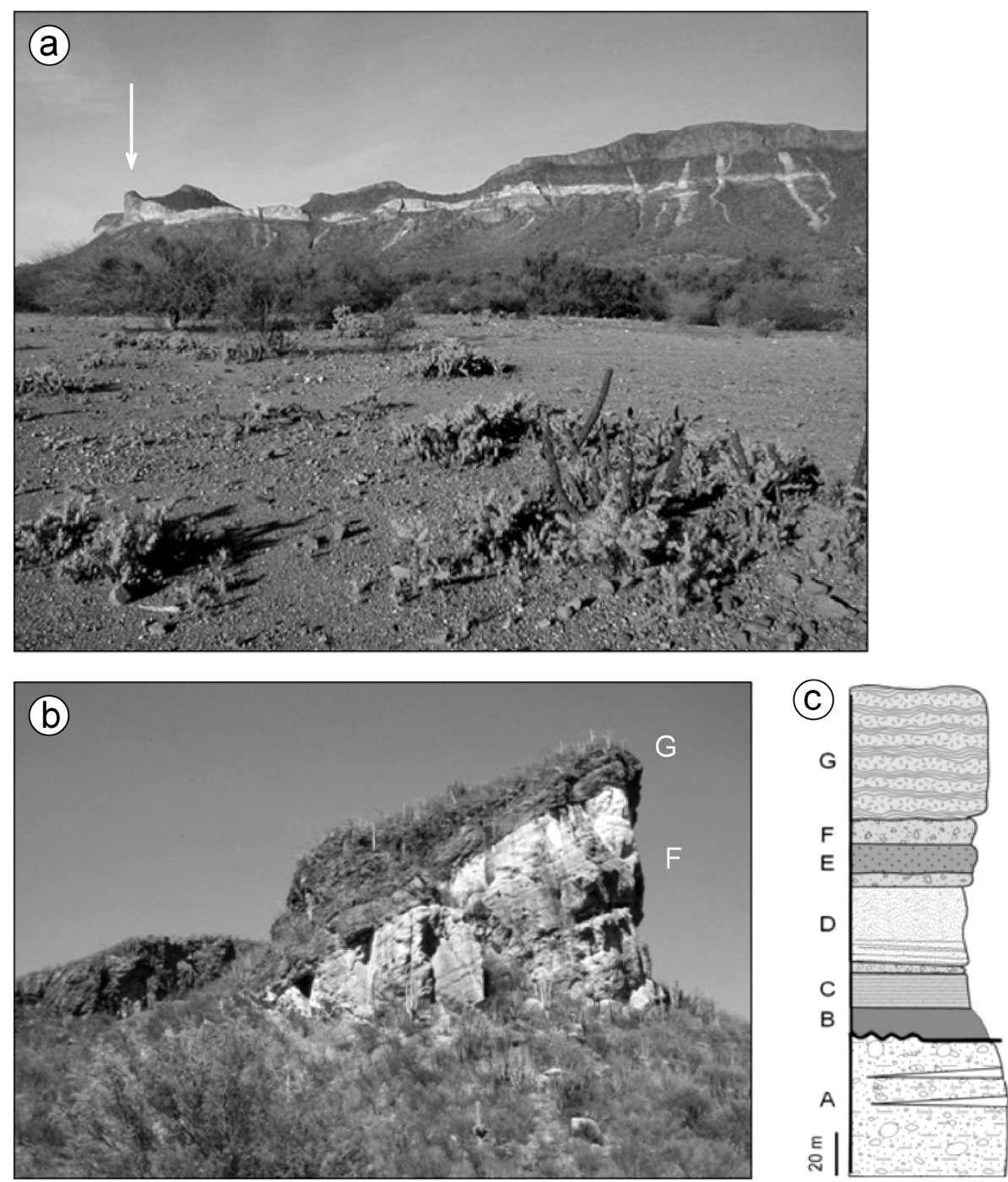

FIG. 3. - Volcanic and sedimentary succession observed at Sierra Lista Blanca (SLB). (a) Overview of the eastern flank of SLB; the arrow indicates the southern part of SLB shown in (b). (b) Photograph of the southern end of SLB showing the icelandite flows (G) and volcano-sedimentary deposits (F), tilted toward the west. In the southern part of SLB, basalts (E) are not represented. (c) Composite stratigraphic column at SLB; A, sandstones and conglomerates (Báucarit Formation); B, welded peralkaline ignimbrite; C, less welded peralkaline unit; D, biotite tuff and volcano-sedimentary deposits forming the whitish stripe on (a); E, basaltic flows intercalated with breccias and conglomerates (F); G, porphyritic glassy lava flows (icelandites).

FIG. 3. - Séquence stratigraphique de la Sierra Lista Blanca (SLB). (a) Vue d'ensemble du flanc est de la SLB ; la flèche marque la partie méridionale de la SLB représentée sur la photographie (b). (b) Photographie de l'extrémité sud de la SLB montrant les coulées d'icelandite (G) et les dépôts volcano-sédimentaires sous-jacents (F) basculés vers l'ouest. Dans cette partie méridionale de la SLB, les basaltes (E) ne sont pas présents. (c) Colonne stratigraphique de la SLB ; A, grès et conglomérats (formation Báucarit) ; $\mathrm{B}$, ignimbrite hyperalcaline soudée ; $\mathrm{C}$, unité ignimbritique hyperalcaline moins soudée; $\mathrm{D}$, tuf à biotite et dépôts volcano-sédimentaires formant le liseré blanc sur la photo (c) ; $\mathrm{E}$, coulées basaltiques intercalées dans des brèches et conglomérats $(\mathrm{F}) ; \mathrm{G}$, coulées vitreuses porphyriques (icelandites).

plot (fig. 7) a trend that does not overlap the field of the SMO ignimbrites [McDowell et al., 1999; Albrecht and Goldstein, 2000; Housh and McDowell, 2005] nor that of the Sierra Santa Ursula (SSU) Miocene sequences [Mora-Klepeis and McDowell, 2004]. Simple assimilation-fractional crystallization (AFC) calculations, based on the correlations between $\mathrm{Nd}$ and $\mathrm{Sr}$ isotope ratios, were used to estimate crustal contamination. For AFC calculations we used the equations of De Paolo [1981], assumed a constant ratio for the rate of mass assimilation to the rate of crystal fractionation, and considered the Hermosillo basalt as the mantle end-member. The range of Sr isotopic compositions of the Middle Miocene ignimbrites can be reproduced by $70-90 \%$ fractional crystallization of this transitional basalt with relatively limited $(r=0.03-0.1)$ assimilation of a highly radiogenic contaminant, which certainly consisted of the Precambrian upper crust represented in northwestern Sonora [Iriondo et al., 2004]. Such a small crustal contribution is not really surprising: given the very low $\mathrm{Sr}$ content of the felsic magma, even a weak assimilation of a highly radiogenic contaminant can rapidly raise the $\mathrm{Sr}$ isotopic ratios. The involvement of an upper crustal contaminant is in agreement with the final stage of differentiation of the peralkaline liquids in a shallow magma chamber. These data, like the isotopic results obtained on the granitoids [Valencia-Moreno et al., 2001], confirm the presence of a Precambrian basement in central and coastal Sonora. On another hand, variations observed in the $\mathrm{Sr}$ and $\mathrm{Nd}$ isotope ratios indicate that Sonoran Middle Miocene peralkaline ignimbrites studied here are not all from a single large-scale volcanic 


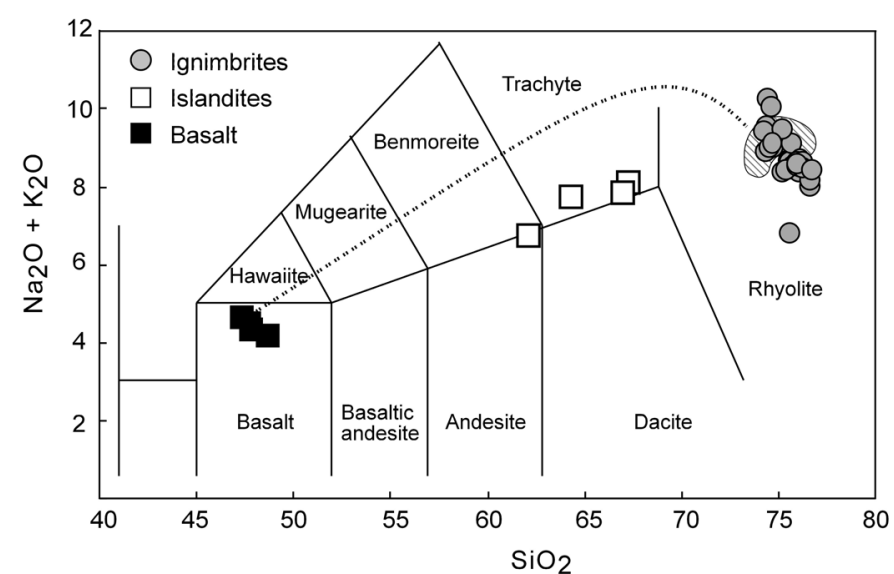

FIG. 4. - Total alkalis silica (TAS) classification diagram [Le Bas et al., 1986; Le Maitre, 1989] for the Middle Miocene Sonoran volcanic rocks. Analyses recalculated to $100 \%$ on a water-free basis. The dashed curve reproduces compositional variations of rocks from the Boina centre, Afar [Barberi et al., 1975]. The hatched field corresponds to comendites from the Primavera caldera, Jalisco [Mahood, 1981].

FIG. 4. - Diagramme alcalins-silice (TAS) [Le Bas et al., 1986; Le Maitre, $1989]$ pour la classification des roches volcaniques de la séquence du Miocène moyen. Analyses recalculées en base anhydre. La courbe en pointillés correspond à l'évolution de la composition chimique des roches du volcan Boina, en Afar [Barberi et al., 1975]. La zone hachurée correspond aux analyses de comendites de la caldera de La Primavera, Jalisco [Mahood, $1981]$.

event such as that hypothesized to have occurred farther to the west [Oskin, 2002]; rather, they may be related to several moderate-volume pyroclastic pulses. The absence of caldera structure is consistent with such independent magma batches rising separately and erupting from distension fractures related to rift evolution. In the Afar depression, a good analogue for illustrating the volcano-tectonic activity linked to rift propagation, silicic lavas erupted prior to the main extensional phase associated with fissural basaltic activity [Lahitte et al., 2003]. In such a context, the time required

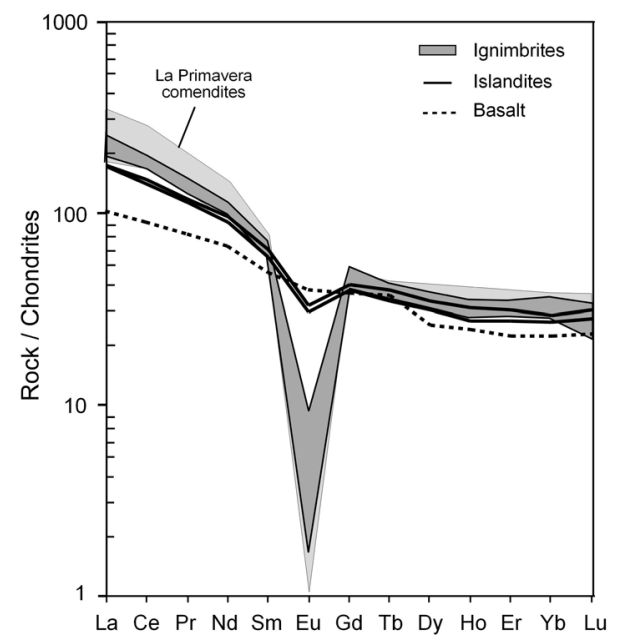

FIG. 5. - Chondrite-normalized REE abundances for the Middle Miocene volcanic rocks from central Sonora. Normalizing values from Sun and McDonough [1989]. REE patterns of La Primavera comendites from Mahood [1981].

FIG. 5. - Diagramme de terres rares normalisé aux chondrites des roches volcaniques de la séquence du Miocène moyen. Valeurs de normalisation de Sun et McDonough [1989]. Spectres de terres rares des comendites de La Primavera d'après Mahood [1981]. for the generation of small-volume rhyolitic melts is relatively short; it has been estimated as less than 50,000 years [Lowenstern et al., 2006].

For the icelandites, AFC calculations [following the method of De Paolo, 1981] show that they could have been derived from $50 \%$ fractional crystallization of a tholeiitic basalt - similar to the Trincheras basalts that crop out south of Sierra Santa Ursula [Paz-Moreno, 1992; Mora-Álvarez and McDowell, 2000] - with limited $(r=0.05)$ assimilation of upper crustal Precambrian material [Vidal-Solano et al., 2006]. The glomeroporphyritic texture and glassy matrix of these rocks require that a basaltic magma trapped in the crust suffers crystal fractionation in a periodically refilled reservoir [Couch et al., 2001] with minor assimilation of Precambrian material, and rises rapidly to the surface [VidalSolano, 2005]. These characteristics illustrate an increase in magma supply rate and an easier access to the surface along fractures related to rifting. The absence of Plio-Quaternary basaltic activity demonstrates that the whole region extending north of Guaymas-Empalme [Paz-Moreno, 1992; Roldán-Quintana et al., 2004; Vargas-Navarro, 2005; Vidal-Solano, 2005] is an aborted rift system.

In brief, $\mathrm{Sr}, \mathrm{Nd}$ and $\mathrm{Pb}$ isotopic data support an origin of the peralkaline ignimbrites by fractional crystallization of transitional basaltic magma, with slight contamination by an old crustal component, which has the characteristics of the Precambrian upper crust. The same mechanisms have been invoked for the SMO or SSU ignimbrites. The isotopic ratios reflect therefore (1) a clear difference in the nature of the basaltic precursor and (2) the peculiar chemistry of the peralkaline liquids i.e. their low Sr contents.

\section{Peralkaline volcanism and the opening of the Gulf of California}

The Middle Miocene peralkaline ignimbrites from central Sonora present many petrochemical similarities with a 12.6 Ma volcanic unit defined as the San Felipe tuff in the Puertecitos area of Baja California [Nagy et al., 1999; Stock et al., 1999; Stock, 2000; Oskin, 2002]. This ignimbritic episode, present in regions that initially correspond to

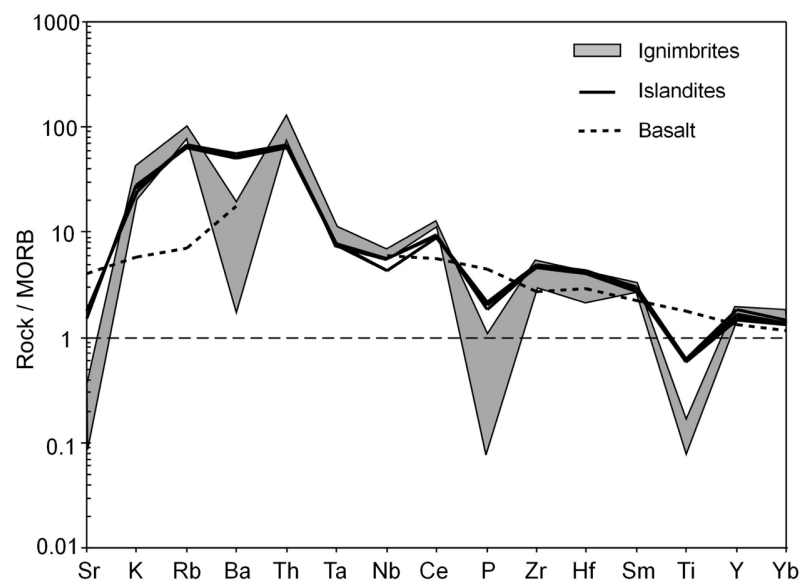

FIG. 6. - MORB-normalized trace element patterns for the Middle Miocene volcanic sequences from central Sonora. Normalizing values from Pearce [1983].

FIG. 6. - Diagramme multi-éléments normalisé aux MORB pour les roches volcaniques de la séquence du Miocène moyen. Valeurs de normalisation de Pearce [1983]. 


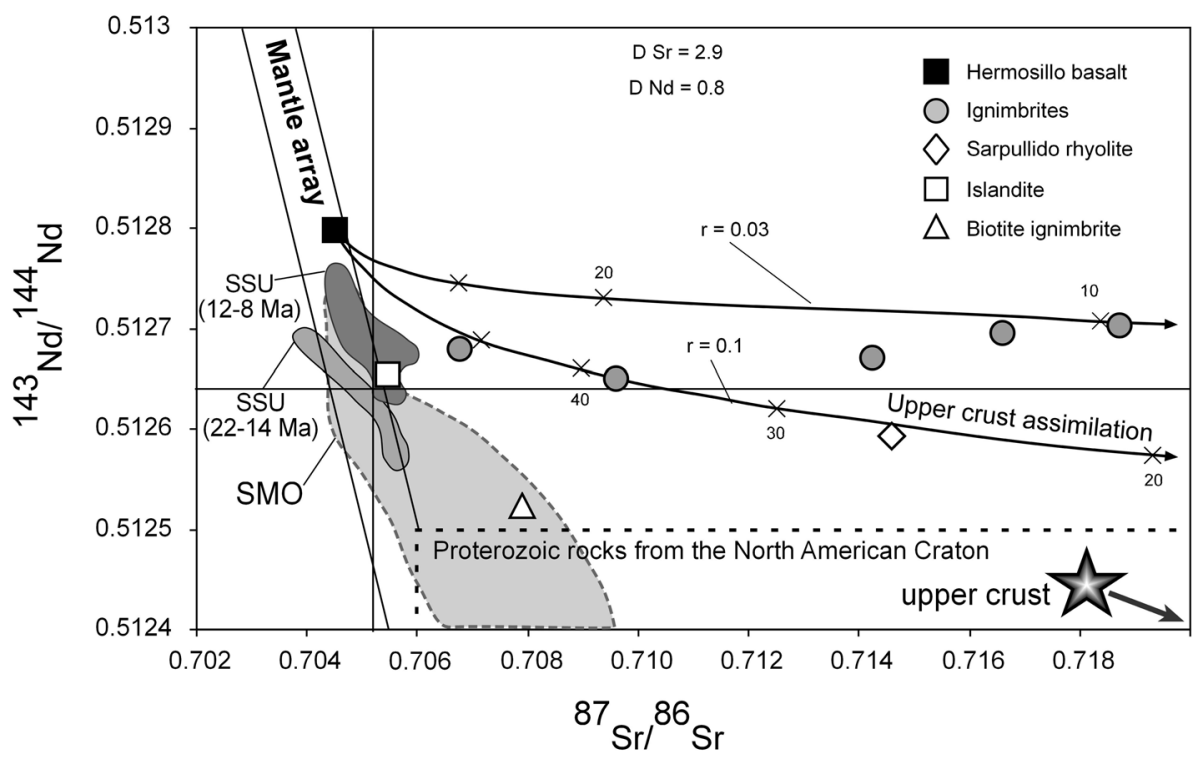

FIG. 7. $-{ }^{143} \mathrm{Nd} /{ }^{144} \mathrm{Nd} v{ }^{87} \mathrm{Sr} /{ }^{86} \mathrm{Sr}$ ratios for Middle Miocene rocks from central Sonora. Additional isotopic ratios from Sierra Santa Ursula (SSU) and the Sierra Madre Occidental (SMO) are used for comparison [Albrecht and Goldstein, 2000; Mora-Klepeis and McDowell, 2004; Housh and McDowell, 2005]. The lines are AFC models [De Paolo, 1981] showing compositional variations of liquids derived from the Hermosillo basalt, assuming the Precambrian upper crust as the contaminant (values of $\mathrm{Sr}=16 \mathrm{ppm}, \mathrm{Nd}=48.4 \mathrm{ppm}, \mathrm{Sri}=0.7390$ and $\mathrm{eNd}=-17.9$ are from Miller et al. [2000]), and ratios between masses of assimilated and fractionated material $\mathrm{r}=0.1$ and 0.03 . Numbers along the lines represent the amounts of residual liquids.

FIG. 7. - Compositions isotopiques ${ }^{143} \mathrm{Nd} /{ }^{144} \mathrm{Nd} v \mathrm{~s}^{87} \mathrm{Sr} / 86 \mathrm{Sr}$ de laves du Miocène moyen du Sonora central. Sont également reportées pour comparaison, des données isotopiques de la Sierra Santa Ursula (SSU) et de la Sierra Madre Occidental (SMO) [Albrecht et Goldstein, 2000; Mora-Klepeis et McDowell, 2004; Housh et McDowell, 2005]. Les courbes correspondent aux modélisations d'AFC selon De Paolo [1981], en considérant la croûte précambrienne supérieure comme le contaminant (valeurs du $\mathrm{Sr}=216 \mathrm{ppm}, \mathrm{Nd}=48.4 \mathrm{ppm}$, Sri $=0.7390$ and eNd $=-17.9$ d'après Miller et al. [2000]), et des rapports entre les masses de matériel assimilé et fractionné compris entre $r=0.1$ et 0.03 . Les chiffres le long des lignes indiquent les pourcentages de liquide résiduel.

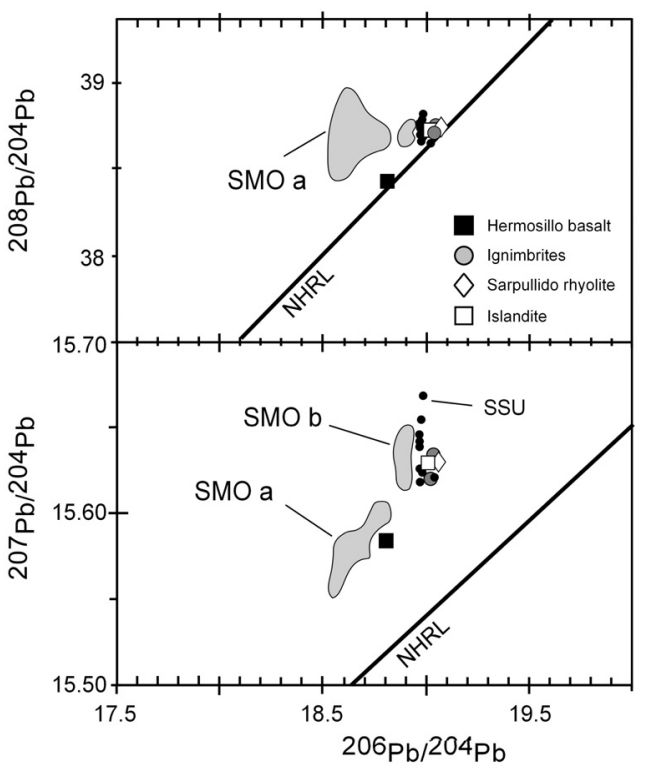

FIG. 8. - Pb isotopic data for Middle Miocene samples from central Sonora. Additional data from Sierra Santa Ursula (SSU, small black dots) [Mora-Klepeis and McDowell, 2004] and the Sierra Madre Occidental (SMO) [Albrecht and Goldstein, 2000; Housh and McDowell, 2005], are used for comparison. SMO a = ignimbrites of the SMO emplaced on the north American basement; SMO b = ignimbrites of the SMO emplaced above accreted terranes.

FIG. 8. - Données isotopiques en plomb de laves du Miocène moyen du Sonora central. Des données de la Sierra Santa Ursula (SSU, points noirs) [Mora-Klepeis et McDowell, 2004] et de la Sierra Madre Occidental (SMO) [Albrecht et Goldstein, 2000; Housh et McDowell, 2005], ont été également reportées pour comparaison. SMO a = ignimbrites de la SMO mises en place sur le craton nord américain; SMO $b=$ ignimbrites de la SMO mises en place au dessus des terrains accrétés. conjugate rifted margins of the Gulf of California [Oskin and Stock, 2003c; Stock et al., 2005], and emplaced during a brief period of time, characterizes the pre-rift stage that precedes continental break-up. It coincides in time with the collision of the Pacific-Farallon ridge with the trench, and the end of subduction [Mammerickx and Klitgord, 1982; Stock and Hodges, 1989; Lonsdale, 1991]. The southern part of the oceanic ridge broke into small ridge segments that were progressively abandoned off Baja California [Michaud et al., 2006; Pallares et al., 2007]. Between 12.5 and $7 \mathrm{Ma}$, the Tosco-Abreojos fault system developed along Baja California to accommodate the relative motion of the Pacific plate [Spencer and Normark, 1979; Stock and Lee, 1994]. Correlations between the preserved remnants of the peralkaline episode on both side of the gulf enable to support a NW-SE strike slip displacement of Baja California of about $280 \mathrm{~km}$ [Oskin et al., 2001; Oskin and Stock, 2003a]. Similarities between the N-S oriented Bahía de los Ángeles and Bahía de las Ánimas grabens in Baja California with the Empalme graben, are also in agreement with this amount of lateral movement (fig. 9).

A drastic change from pre-rift E-W extension to syn-rift NW-SE transtensional regime occurred at the end of the Miocene. It is documented in central Sonora by (1) the tilting of the $12.5 \mathrm{Ma}$ ignimbrite mesas and their icelandite cover, and (2) the presence of strike-slip duplexes at Cerro Sarpullido [Vidal-Solano, 2005]. In the gulf area, NW-SE striking faults that limit the Yaqui half-graben offshore Sonora, and the Guaymas half-graben, offshore Baja California [Aragón-Arreola et al., 2005], are considered to have accommodated the transtensional strain associated with the 


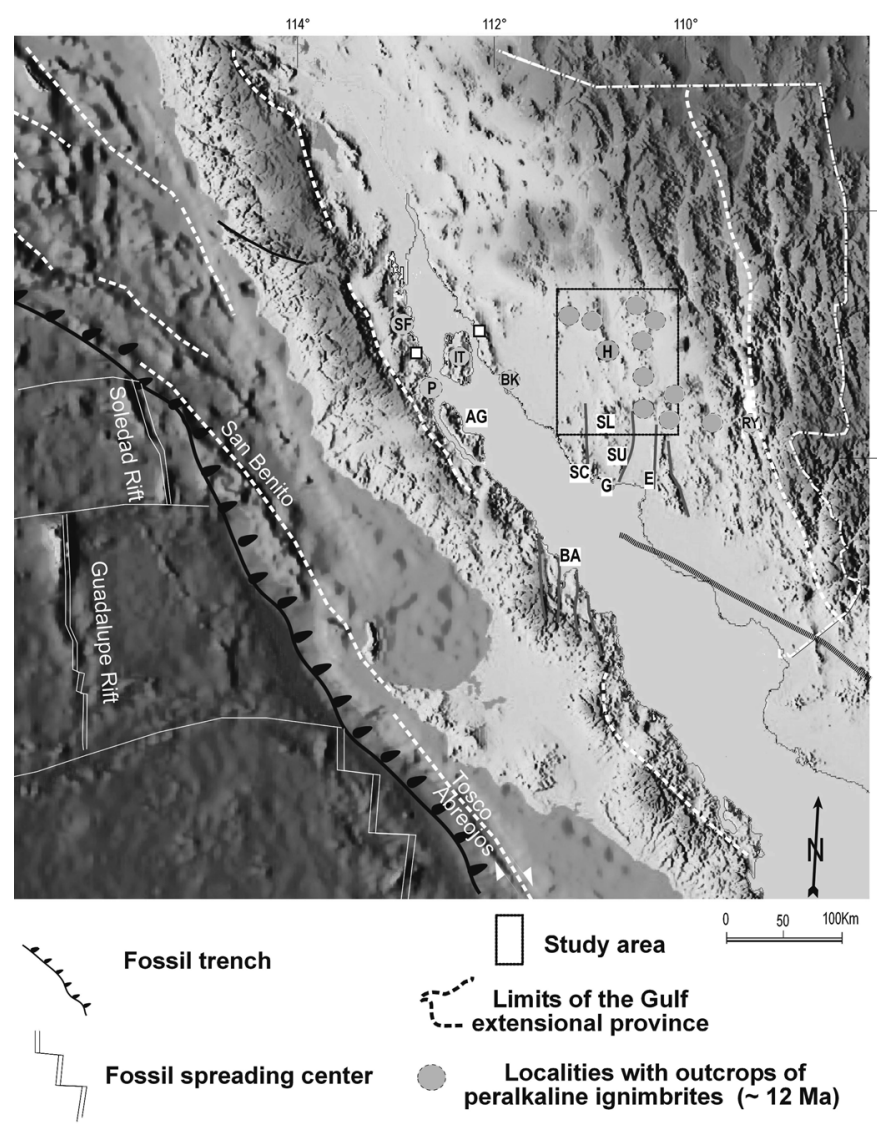

Limit of the precambrian basement?
FIG. 9. - Schematic reconstruction of the initial position of Baja California peninsula, and major crustal blocks that became large gulf islands, relative to Sonora in late Miocene time. The relief image used in that figure, generated from the ETOPO2v2 (2006) database, is available on http://www.ngdc.noaa.gov/mgg/image/2minrelief.html. The San Felipe and Puertecitos areas in Baja California, Tiburón Island and Bahia Kino in coastal Sonora contains numerous outcrops of a peralkaline ignimbrite, the Tuff of San Felipe, which erupted ca. $12.5 \mathrm{Ma}$, prior to the opening of the gulf. This ignimbrite, and a series of younger ( $6 \mathrm{Ma})$ ignimbrites are used to constrain the reconstructed positions of these blocks [Oskin and Stock, 2003a, $2003 \mathrm{c}$. G-E = Guaymas-Empalme graben; BA = double graben system of Bahia de Los Angeles (west) and Bahia de las Animas (east); SF = San Felipe; $\mathrm{P}=$ Puertecitos (on eastern coast of Baja California) $; \mathrm{BK}=$ Bahia de Kino; $\mathrm{AG}=$ Angel de la Guardia Island; $\mathrm{H}=$ Hermosillo; $\mathrm{SL}=$ Sierra Libre; $\mathrm{RY}=$ Río Yaqui, easternmost outcrop of peralkaline ignimbrite. White squares are additional constraints on this reconstruction and correspond to the locations of pre-Miocene fluvial conglomerates inferred to have been deposited in a westward-draining river system, correlated from Sonora to Baja California by Gastil et al. [1973].

FIG. 9. - Reconstitution de la position initiale de la partie nord de la péninsule de Basse Californie, et des blocs crustaux qui forment les îles du golfe, par rapport au Sonora au Miocène moyen. La base topographique utilisée est une image générée par la base de données ETOPO2v2 (2006) disponible sur le site http://www.ngdc.noaa.gov/mgg/image/2minrelief.html. La région de San Felipe - Puertecitos en Basse Californie, l'île Tiburón et le secteur de Bahia de Kino sur la côte du Sonora, sont des secteurs où affleurent des ignimbrites hyperalcalines datées de 12.5 Ma (Tuff San Felipe), mises en place avant l'ouverture du golfe. Cette ignimbrite, ainsi que les ignimbrites plus récentes (6 Ma), ont servi à reconstituer le déplacement de la Basse Californie [Oskin et Stock, 2003a, 2003c]. RY = Río Yaqui, affleurement d'ignimbrite hyperalcaline le plus oriental. Les carrés blancs correspondent à des conglomérats fluviatiles anté-miocènes trouvés de part et d'autre du golfe, considérés par Gastil et al. [1973] comme la marque d'un drainage vers l'ouest depuis le Sonora. progressive transfer of Baja California to the Pacific plate. Marine incursion into the gulf area occurred at about 6.5 Ma, when most of the motion between Pacific and North-American plates was localized within the Gulf of California [Klitgord and Mammerickx, 1982; Stock and Hodges, 1989; Oskin et al., 2001; Castillo et al., 2002; Oskin and Stock, 2003b, 2003c].

At this point a first-order question arises: why did peralkaline magmatism occur only in central Sonora and the Puertecitos area, during the pre-rift Middle Miocene episode? For the genesis of peralkaline silicic melts two conditions are needed: (1) a tectonic regime that enables the liquids to be trapped at an upper crustal level thereby enhancing fractional crystallization under low pressure conditions, and (2) the presence of the Precambrian craton to raise the ${ }^{87} \mathrm{Sr} /{ }^{86} \mathrm{Sr}$ ratio of the differentiated liquids. Central Sonora Middle Miocene comendites are located on a major boundary between the Precambrian crust and the Mesozoic accreted terranes [Tardy et al., 1994]. In southwestern United States, Middle Miocene peralkaline volcanism also commonly appears after a long period of subduction-related magmatism [Best et al., 1989]. Its distribution, from Nevada to California [Scott et al., 1995; Perkins and Nash, 2002], and down to the Pinacate area [Vidal-Solano et al., 2008], follows the western edge of the Precambrian basement. Because an old crust has a brittle behaviour, it favours the rapid ascent of parental magmas from the lower crust into shallow magma reservoirs. Geochemistry clearly points to transitional basalts as potential parent magmas for the comendites; this implies (1) a weakened continental crust and (2) the absence of a subducted slab in that part of the gulf extensional province. However, the calc-alkaline signatures of Middle to Late Miocene volcanic sequences in SSU [Mora-Álvarez and McDowell, 2000] or the Puertecitos area [Martín-Barajas et al., 1995; Nagy et al., 1999], show that subduction-modified supraslab mantle can be preserved locally highlighting the complexity of the lithospheric structure at the edge of the North-American craton [Miller et al., 2000; Vidal-Solano et al., 2008]. Finally, the good fit between the location of peralkaline volcanism and the limit of the southern California slab window at $12.5 \mathrm{Ma}$ [Wilson et al., 2005; Pallares et al., 2007], is obviously not fortuitous.

\section{CONCLUSION}

Peralkaline ignimbrites erupted during Middle Miocene times either in central Sonora or the Puertecitos area, in Baja California, are a good geodynamic marker of the structural evolution of the Gulf of California rift system. This volcanic episode has petrochemical characteristics clearly different from those of the other Miocene volcanic sequences, indicating a change in the mantle source. Isotopic signatures, as well as the lack of caldera collapse post-dating the eruption, show that the $12.5 \mathrm{Ma}$ peralkaline ignimbrites of central Sonora correspond to small independent magma batches evolving in shallow reservoirs rather than to a single large volume erupting system. Moreover, isotopes support 
an origin by closed-system fractionation of transitional basalts with slight contamination by the Precambrian upper crust. Less differentiated $11 \mathrm{Ma}$ old icelandites correspond to slightly higher magma supply and slower cooling rates in opened-magma chambers, illustrating an easier access to the surface at that time. The lack of recent voluminous basaltic outpourings shows however that the initial Middle Miocene intra-continental propagating rift has not evolved toward a more mature stage. The early rift system was abandoned in the Late Miocene, when Baja California peninsula became progressively coupled with the Pacific plate. The peralkaline magmatic activity allows us to document the limit of the Precambrian craton, and the presence of an asthenospheric window below the region at $12.5 \mathrm{Ma}$.

Acknowledgements. - This study is part of the Ph.D. thesis of the senior author at the Université Paul Cézanne (Aix-Marseille 3). This work was funded by CONACYT and SFERE (129313/168910) scholarship grant. Sampling and mapping were carried out from 1999 to 2005 with the financial support of the Departamento de Geología de la Universidad de Sonora. Thanks to M.O. Trensz (ICP-AES analyses, CEREGE) to J.-C. Girard (thin-section preparation) and C. Merlet (electron microprobe, ISTEEM Montpellier). ENS Lyon supported $\mathrm{Pb}$ isotope facilities. This work also benefited from a 6 months post-doctoral fellowship at Seismo Lab in Caltech, supported by the US National Science Foundation grant EAR-0336961. Reviews by Christian Picard and Marc Tardy help to improve the manuscript.

\section{References}

Albrecht A. \& Goldstein S.L. (2000). - Effects of basement composition and age on silicic magmas across an accreted terrane-Precambrian crust boundary, Sierra Madre Occidental, Mexico. - J. South Amer. Earth Sci., 13, 255-273.

Aragón-Arreola M., Morandi M., Martín-Barajas A., Delga Do-Argote L. \& GonZález-Fernández A. (2005). - Structure of the rift basins in the central gulf of California: Kinematic implications for oblique rifting. - Tectonophysics, 409, 19-38.

BARBERI F., SANTACROCE R. \& VARET J. (1974). - Silicic peralkaline volcanic rocks of the Afar depression (Ethiopia). In: D.K. BAILEY, F BARBERI \& R. MACDONALD, Eds, Oversaturated peralkaline volcanic rocks. - Bull. Volcanol., 38, 755-790.

Barberi F., Ferrara G., Santacroce R., Treuil M. \& Varet J. (1975). A transitional basalt-pantellerite sequence of fractional crystallization, the Boina centre (Afar rift, Ethiopia). - J. Petrol., 16, 22-56.

Barrat J.A., Keller F., Amossé J., Taylor R.N., Nesbitt R.W. \& Hirata T. (1996). - Determination of rare earth elements in sixteen silicate reference samples by ICP-MS using a Tm addition and ion-exchange chromatography procedure. - Geostand. Newsl., 20, 133-139.

Bartolini C., Morales-Montaño M., Damon P.E. \& Shafiqullah M (1992). - K-Ar ages of tilted tertiary volcanic rocks associated with continental conglomerates, Sonoran basin and Range Province, México. - Geol. Soc. Amer. Abstr. Prog., 24, 6.

Bartolini C., Damon P.E., Shafiqullah M. \& Morales-Montaño M. (1994). - Geochronologic contribution to the Tertiary sedimentary-volcanic sequences (Báucarit Formation) in Sonora, México. - Geofís. Intern., 33, 67-77.

Best M.G., Christiansen E.H., Deino A.L., Gromme C.S., Mckee E.H. \& Noble D.C. (1989). - Excursion 3A: Eocene through Miocene volcanism in the Great Basin of the western United States. In: C.E. CHAPIN \& J. ZIDEK, Eds., Field excursions to volcanic terranes in the western United States, volume II: Cascades and intermountain west. - New Mexico Bureau Min. \& Mineral Res. Memoir, 47, 91-133.

Bizouard H., Barberi F. \& Varet J. (1976). - Minéralogie des séries volcaniques axiales de l'Afar: précisions sur les processus et les conditions de fractionnement des magmas basaltiques dans les zones en accrétion. - Bull. Soc. géol. Fr., (7), XVIII, 837-840.

Bizouard H., BARberi F. \& VARET J. (1980). - Mineralogy and petrology of Erta Ale and Boina volcanic series, Afar rift, Ethiopia. - J. Petrol., 21, 401-436.

Black S., Macdonald R. \& Kelly M.R. (1997). - Crustal origin for peralkaline rhyolites from Kenya: evidence from U-series disequilibria and Th-isotopes. - J. Petrol., 38, 277-297.

BoHRson W.A. \& ReID M.R. (1997). - Genesis of silicic peralkaline volcanic rocks in a ocean island setting by crustal melting and open system processes: Socorro Island, Mexico. - J. Petrol., 38, 1137-1166.
Caricchi L., Ulmer P. \& Peccerillo A. (2006). - A high-pressure experimental study on the evolution of the silicic magmatism of the Main Ethiopian rift. - Lithos, 91, 46-58.

Castillo P.R., Hawkins J.W., Lonsdale P.F., Hilton D.R., Shaw A.M. \& Glascock M.D. (2002). - Petrology of Alarcon Rise lavas, Gulf of California: Nascent intracontinental ocean crust. - J. Geophys. Res., 107, 2222. doi: 10.1029/2001JB000666.

Civetta L., D'antonio M., Orsi G. \& Tilton G.R. (1998). - The geochemistry of volcanic rocks from Pantelleria Island, Sicily channel: petrogenesis and characteristics of the mantle source region. $-J$. Petrol., 39, 1453-1491.

Couch S., Sparks R.S.J. \& Carroll M.R. (2001). - Mineral disequilibrium in lavas explained by convective self-mixing in open magma chambers. - Nature, 411, 1037-1039.

Davies J.R. \& Macdonald R. (1987). - Crustal influence in the petrogenesis of the Naivasha basalt-comendite complex: combined trace element and $\mathrm{Sr}-\mathrm{Nd}-\mathrm{Pb}$ isotope constraints. - J. Petrol., 28, 1009-1031.

DE Paolo D.J. (1981). - Trace element and isotopic effects of combined wallrock assimilation and fractional crystallization. - Earth Planet. Sci. Lett., 53, 189-202.

EdWARDS B.R. \& RUSSELL J.K. (2000). - Distribution, nature, and origin of Neogene-Quaternary magmatism in the northern Cordilleran volcanic province, Canada. - Geol. Soc. Amer. Bull., 112, 1280-1295.

GANS P.B. (1997). - Large-magnitude Oligo-Miocene extension in southern Sonora: Implications for the tectonic evolution of northwest Mexico. - Tectonics, 16, 388-408.

Gans P.B., Blair K., Macmillan I., Wong M. \& Roldán-Quintana J. (2003). - Structural and magmatic evolution of the Sonoran rifted margin: a preliminary report. - Geol. Soc. Amer. Abstr. Prog., 34 (6), electronic abstract.

Gasparon M., Innocenti F., Manetti P., Peccerillo A. \& Tsegaye A. (1993). - Genesis of the Pliocene to recent bimodal mafic-felsic volcanism in the Debre Zeit area, Central Ethiopia: Volcanological and geochemical constraints. - J. Afr. Earth Sci., 17, $145-165$.

Gastil R.G., Lemone D.V. \& Stewart W.J. (1973). - Permian fusulinids from near San Felipe, Baja California. - Amer. Assoc. Petrol. Geol. Bull., 57, 746-747.

Housh T.B. \& Mcdowell F.W. (2005). - Isotopic provinces in Laramide and mid-Tertiary igneous rocks of northwestern Mexico (Chihuahua and Sonora) and their relation to basement configuration. In: T.H. Anderson, J.A. Nourse, J.W. Mckee \& M.B. STEINER, Eds., The Mojave-Sonora megashear hypothesis: development, assessment, and alternatives. - Geol. Soc. Amer. Sp. Paper, 393, 671-692. 
Iriondo A., Premo W.R., Martínez-Torres L.M., Budahn J.R., AtKinson W.W., Siems D.F. \& GuARÁS-GonZÁleZ B. (2004). - Isotopic, geochemical, and temporal characterization of Proterozoic basement rocks in the Quitovac region, northwestern Sonora, Mexico: implications for the reconstruction of the southwestern margin of Laurentia. - Geol. Soc. Amer. Bull., 116, 154-170.

KLitgord K.D. \& Mammerickx J. (1982). - North East Pacific Rise: Magnetic anomaly and bathymetric framework. - J. Geophys. Res., 87, 6725-6750.

Lahitte P., Gillot P-Y. \& Courtillot V. (2003). - Silicic central volcanoes as precursors to rift propagation: the Afar case. - Earth Planet. Sci. Lett., 207, 103-116.

Lapierre H., Dupuis V., Mercier De Lepinay B., Tardy M., Ruiz J., MauRY R.C., Hernandez J. \& Loubet M. (1997). - Is the Lower Duarte igneous complex (Hispaniola) a remnant of the Caribbean plume-generated oceanic plateau?. - J. Geol., 105, 111-120.

Le Bas M.J., Le Maitre R.W., Streckeisen A. \& Zanettin B. (1986). - A chemical classification of volcanic rocks based on the total alkali-silica diagram. - J. Petrol., 27, 745-750.

Le Maitre R.W. (1989). - A classification of igneous rocks and glossary of terms. - Blackwell Scientific Publications, Oxford, 193 p.

Lightfoot P.C., Hawkesworth C.J. \& Sethna S.F. (1987). - Petrogenesis of rhyolites and trachytes from the Deccan trap: $\mathrm{Sr}, \mathrm{Nd}$ and $\mathrm{Pb}$ isotope and trace element evidence. - Contrib. Mineral. Petrol. 95, 44-54.

LONSDAlE P. (1991) - Structural patterns of the Pacific floor offshore of peninsular California. In: J.P. DAUPHIN \& B.A. SimONEIT, Eds, The Gulf and Peninsular Province of the Californias. - Amer. Assoc. Petrol. Geol., 47, 87-125.

Lowenstern J.B. \& Mahood G.A. (1991). - New data on magmatic $\mathrm{H}_{2} \mathrm{O}$ contents of pantellerite, with implications for petrogenesis and eruptive dynamics at Pantelleria. - Bull. Volcanol., 54, 78-83.

Lowenstern J.B., Clynne M.A. \& Bullen T.D. (1997). - Comagmatic A-type granophyre and rhyolite from the Alid volcanic center, Eritrea, northeast Africa. - J. Petrol., 38, 1707-1721.

Lowenstern J.B., Charlier B.L.A., Clynne M.A. \& Wooden J.L. (2006). - Extreme U-Th disequilibrium in rift-related basalts, rhyolites and granophyric granite and the timescale of rhyolite generation, intrusion and crystallization at Alid volcanic center, Eritrea. - J. Petrol., 47, 2105-2122.

MACDONALD R. (1974a). - Nomenclature and geochemistry of the peralkaline oversaturated extrusive rocks. In: D.K. BAILEY, F. BARBERI \& R. Macdonald, Eds., Oversaturated peralkaline volcanic rocks. - Bull. Volcanol., 38, 498-516.

MACDONALD R. (1974b). - Tectonic settings and magma associations. In: BAiley D.K., BARBERI F. \& MACDONALd R., Eds., Oversaturated peralkaline volcanic rocks. - Bull. Volcanol., 38, 575-593.

Macdonald R., Davies G.R., Bliss C.M., Leat P.T., Bailey D.K. \& SMith R.L. (1987). - Geochemistry of high-silica rhyolites, Naivasha, Kenya rift Valley. - J. Petrol., 28, 979-1008.

MAHOOD G.A. (1980) - Geochemical evolution of a Pleistocene rhyolitic center: Sierra La Primavera, Jalisco, Mexico. - J. Volcanol. Geotherm. Res., 8, 199-230.

Mahood G.A. (1981) - Chemical evolution of a Pleistocene rhyolitic center: Sierra La Primavera, Jalisco, Mexico. - Contrib. Mineral. Petrol., 77, 129-149.

Mahood G.A. (1984). - Pyroclastic rocks and calderas associated with strongly peralkaline magmatism. - J. Geophys. Res., 89, $8540-8552$.

MAHOOD G.A. \& BAKER D.R. (1986). - Experimental constraints on depth of fractionation of mildly alkalic basalts and associated felsic rocks: Pantelleria, strait of Sicily. - Contrib. Mineral. Petrol., 93, 251-264.

Mahood G.A., Hallyday A.N. \& Hildreth W. (1990). - Isotopic evidence for the origin of pantellerites in a rift related alkalic suite: Pantelleria, Italy. - IAVCEI Abstr. Mainz, Germany.

Mammerickx J. \& Klitgord K.M. (1982). - Northern East Pacific Rise: evolution from 25 m.y. B.P. to the Present. -J. Geophys. Res., 87, 6751-6759.

Manhès G., Allègre C.J., Dupré B. \& Hamelin B. (1980). - Lead isotope study of basic-ultrabasic layered complex: speculations about the ages of the Earth and primitive mantle characteristics. Earth Planet. Sci. Lett., 43, 370-382.
Martín-Barajas A., Stock J.M., Layer P., Hausback B., Renne P. \& LóPEZ-MARTínez M. (1995). - Arc-rift transition volcanism in the Puertecitos Volcanic Province, northeastern Baja California, Mexico. - Geol. Soc. Amer. Bull., 107, 407-424.

Mcdowell F.W., Roldán-Quintana J. \& Amaya-Martínez R. (1997). Inter-relationship of sedimentary and volcanic deposits associated with Tertiary extension in Sonora, Mexico. - Geol. Soc. Amer. Bull., 109, 1349-1360.

Mcdowell F.W., Housh T.B. \& Wark D.A. (1999). - Nature of the crust beneath west-central Chihuahua, Mexico, based upon $\mathrm{Sr}, \mathrm{Nd}$, and $\mathrm{Pb}$ isotopic compositions at the Tomóchic volcanic center. Geol. Soc. Amer. Bull., 111, 823-830.

Michaud F., Royer J.-Y., Bourgois J., Dyment J., Calmus T., Bandy W., Sosson M., Mortera-Gutiérrez C., Sichler B., RebolleDo-Viera M. \& Pontoise B. (2006). - Oceanic-ridge subduction vs. slab break-off: Plate tectonic evolution along the Baja California Sur continental margin since 15 Ma. - Geology, 34, 13-16.

Miller J.S., Glazner A.F., Farmer G.L., Suayab I.B. \& Keith L.A. (2000). - A Sr, Nd, and Pb isotopic study of mantle domains and crustal structure from Miocene volcanic rocks in the Mojave Desert, California. - Geol. Soc. Amer. Bull., 112, 1264-1279.

Mora-Álvarez G. \& Mcdowell F.W. (2000). - Miocene volcanism during late subduction and early rifting in the Sierra Santa Ursula of western Sonora, Mexico. In: H. Delgado-Granados, G. Aguirre-Díaz \& J.M. Stock, Eds., Cenozoic tectonics and volcanism of Mexico. - Geol. Soc. Amer. Sp. Paper, 334, 123-141.

MorA-Klepeis G. \& Mcdowell F.W. (2004). - Late Miocene calc-alkalic volcanism in northwestern Mexico: an expression of rift or subduction-related magmatism?. - J. South Amer. Earth Sci., 17, 297-310.

Morales-Montaño M., Bartolini C., Damon P.E. \& Shafiqullah M. (1990). - K-Ar dating, stratigraphy and extensional deformation of Sierra Lista Blanca, Central Sonora, México. - Geol. Soc. Amer. Abstr. Prog., 22 (6), 73.

Mungall J.E. \& Martin R.F. (1995). - Petrogenesis of basalt-comendite and basalt-pantellerite suites, Terceira, Azores and some implications for the origin of the ocean-islands rhyolites. - Contrib. Mineral. Petrol., 119, 43-55.

NAgy E.A., Grove M. \& Stock J.M. (1999). - Age and stratigraphic relationships of pre- and syn-rift volcanic deposits in the northern Puertecitos Volcanic Province, Baja California, Mexico. - J. Volcanol. Geotherm. Res., 93, 1-30.

Oskin M.E. (2002). - Tectonic evolution of the northern Gulf of California, México, deduced from conjugate rifted margins of the upper Delfín Basin. - Unpublished Ph.D. thesis, California Institute of Technology, Pasadena, 487 pp.

Oskin M.E. \& Stock J.M. (2003a). - Pacific-North America plate motion and opening of the Upper Delfín basin, northern Gulf of California. - Geol. Soc. Amer. Bull., 115, 1173-1190.

Oskin M.E. \& STOck J.M. (2003b). - Marine incursion synchronous with plate-boundary localization in the Gulf of California. - Geology, 31, 23-26.

Oskin M.E. \& Stock J.M. (2003c). - Cenozoic volcanism and tectonics of the continental margins of the Upper Delfin basin, northeastern Baja California and western Sonora. In: S.E. Johnson, S.R. PAterson, J.M. Fletcher, G.H. Girty, D.L. Kimbrough \& A. Martín-BARAJAs, Eds., Tectonic evolution of northwestern México and southwestern USA. - Geol. Soc. Amer. Sp. Paper, 374, 421-438.

Oskin M.E., Stock J.M. \& Martín-Barajas A. (2001). - Rapid localization of Pacific-North America plate motion in the Gulf of California. - Geology, 29, 459-462.

Pallares C., Maury R.C., Bellon H., Royer J-Y., Calmus T., Aguillón-Robles A., Cotten J., Benoit M., Michaud F. \& Bourgois J. (2007). - Slab-tearing following ridge-trench collision: Evidence from Miocene volcanism in Baja California, México. - J. Volcanol. Geotherm. Res., 161, 95-117.

PAZ-Moreno F.A. (1992). - Le volcanisme mio-plio-quaternaire de l'Etat du Sonora (nord-ouest du Mexique): évolution spatiale et chronologique ; implications pétrogénétiques. - Unpublished Ph.D. thesis, Université Aix-Marseille III, 220 pp. 
Paz-Moreno F.A., Demant A., Cochemé J-J., Dostal J. \& Montigny R. (2003). - The Quaternary Moctezuma volcanic field: a tholeiitic to alkalic volcanic episode in the central Sonoran Basin and Range Province, México. In: S.E. Johnson, S.R. Paterson, J.M. Fletcher, G.H. Girty, D.L. Kimbrough \& A. Martín-Barajas, Eds, Tectonic evolution of northwestern México and southwestern USA. - Geol. Soc. Amer. Sp. Paper, 374, 439-455.

PEARCE J.A. (1983). - Role of subcontinental lithosphere in magma genesis at active continental margins. In: C.J. HAwKESWORTH \& M.J. NORry, Eds, Continental basalts and mantle xenoliths. - Shiva Geology series, Nantwich, 230-249.

Peccerillo A., Barberio M.R., Yirgu G., Ayalew D., Barbieri M. \& Wu T.W. (2003). - Relationship between mafic and peralkaline silicic magmatism in continental rift setting: a petrological, geochemical and isotopic study of the Gedemsa volcano, central Ethiopian rift. - J. Petrol., 44, 2003-2032.

PERKINS M.E. \& NASH B.P. (2002). - Explosive silicic volcanism of the Yellowstone hotspot: The ash fall tuff record. - Geol. Soc. Amer. Bull., 114, 367-381.

Roldán-Quintana J., Mora-Klepeis G., Calmus T., Valencia-Moreno M. \& LozANO-SANTACRUZ R. (2004). - El graben de Empalme, Sonora, México: magmatismo y tectónica extensional asociados a la ruptura del golfo de California. - Rev. Mex. Ciencias Geol., 21, 320-334.

Scaillet B. \& Macdonald R. (2001). - Phase relations of peralkaline silicic magmas and petrogenetic implications. - J. Petrol., 42, 825-845.

Scott R.B., Unruh D.M., Snee L.W., Harding A.E., Nealey L.D., Blank H.R., BudAhn J.R. \& MEHNERT H.H. (1995). - Relation of peralkaline magmatism to heterogeneous extension during the middle Miocene, southeastern Nevada. - J. Geophys. Res., 100, 10381-10401.

SPENCER J.E. \& Normark W.R. (1979). - Tosco-Abreojos fault zone: A Neogene transform plate boundary within the Pacific margin of southern Baja California, Mexico. - Geology, 7, 554-557.

Stock J.M. (2000). - Relation of the Puertecitos Volcanic Province, Baja California, Mexico, to development of the plate boundary in the Gulf of California. In: $\mathrm{H}$. Delgado-Granados, $\mathrm{G}$ Aguirre-Díaz \& J.M. Stock, Eds., Cenozoic tectonics and volcanism of Mexico. - Geol. Soc. Amer. Sp. Paper, 334, 123-141.

Stock J.M. \& Hodges K.V. (1989). - Pre-Pliocene extension around the Gulf of California and the transfer of Baja California to the $\mathrm{Pa}$ cific Plate. - Tectonics, 8, 99-115.

Stock J.M. \& LeE J. (1994). - Do microplates in subduction zones leave a geological record? - Tectonics, 13, 1472-1487.

Stock J.M., Lewis C.J. \& NAGy E.A. (1999). - The tuff of San Felipe: an extensive middle Miocene pyroclastic flow deposit in Baja California, Mexico. - J. Volcanol. Geotherm. Res., 93, 53-74.

Stock J.M., Martin K. \& Paz-Moreno F.A. (2005). - Extensión de la Toba San Felipe desde Baja California hasta el interior de Sonora. - GEOS, 25, 84-85.

Stroncik N.A. \& Schmincke H-U. (2002). - Palagonite - a review. Intern. J. Earth Sci. (Geologisch Rundschau), 91, 680-697.

Sun S.S. \& Mcdonough W.F. (1989). - Chemical and isotopic systematics of oceanic basalts: implications for mantle compositions and process. In: A.D. SAUnders \& M.J. NorRY, Eds., Magmatism in the ocean basins. - Geol. Soc. London Spec. Publ., 42, 313-345.
SutherLAND D.S. (1974). - Petrography and mineralogy of the peralkaline silicic rocks. In: D.K. BAILEY, F. BARBERI \& R. MACDONALD, Eds., Oversaturated peralkaline volcanic rocks. - Bull. Volcanol., 38, 517-547.

Tardy M., Lapierre H., Freydier C., Coulon C., Gill J.B., Mercier De Lépinay B., Beck C., Martínez-Reyes J., Talavera M.O. Ortiz E., Stein G., Bourdier J.L. \& Yta M. (1994). - The Guerrero suspect terrane (western Mexico) and coeval arc terranes (Greater Antilles and western Cordillera of Colombia): a Late Mesozoic intra-oceanic arc accreted to cratonal America during the Cretaceous. - Tectonophysics, 230, 49-73.

Todt W., Cliff R.A., Hanser A. \& Hofmann A.W. (1996). - Evaluation of a ${ }^{202} \mathrm{~Pb} /{ }^{205} \mathrm{~Pb}$ double spike for high-precision lead isotope analysis. In: A. BASU \& S. HART, Eds., Earth processes: Reading the isotopic code. - Geophys. Monograph, Amer. Geophys. Union, 95, 429-437.

Valencia-Moreno M., Ruiz J., Barton M.D., Patchett P.J., ZÜrcher L., Hodkinson D.G. \& RoldÁn-Quintana J. (2001). - A chemical and isotopic study of the Laramide granitic belt of northwestern Mexico: identification of the southern edge of the North American Precambrian basement. - Geol. Soc. Amer. Bull., 113, 1409-1422.

VArgas-NaVArro P.P. (2005). - La cuenca de Empalme, Sonora: petrogénesis de las rocas ígneas neógenas y su análisis estructural. Unpublished Master thesis, Universidad Nacional Autónoma de Mexico, 107 pp.

VIDAL-SOLANO J.R. (2005). - Le volcanisme hyperalcalin d'âge miocène moyen du nord-ouest du Mexique (Sonora). Minéralogie, géochimie, cadre géodynamique. - Unpublished Ph.D. thesis, Université Paul Cézanne (Aix-Marseille 3), 256 pp. [http: //tel.ccsd.cnrs.fr/tel-00010346]

Vidal-Solano J.R., Paz-Moreno F.A., Iriondo A., Demant A. \& CocheMÉ J-J. (2005). - Middle Miocene peralkaline ignimbrites in the Hermosillo region (Sonora, México). Geodynamic implications. - C. R. Geoscience, 337, 1421-1430.

Vidal-Solano J.R., Paz-Moreno F.A. \& Demant A. (2006). - Una serie pigeonítica del Mioceno medio-superior en Sonora: Marcador de la evolución magmática en el rift del Proto-Golfo de California. - XVI Congreso Nacional de Geoquímica, Mérida, Yucatán, México. - Actas INAGEQ, 12(1), S 8 (4), 6-12.

Vidal-Solano J.R., Paz-Moreno F.A., Demant A. \& López-Martínez M. (2007). - Ignimbritas hiperalcalinas del Mioceno medio en Sonora Central: revaluación de la estratigrafía y del significado del volcanismo terciario. - Rev. Mex. Ciencias Geol., 24, 47-67.

Vidal-Solano J.R., Demant A., PaZ-Moreno F.A., Lapierre H., OrtegaRIVERA M.A. \& LEE J.K.W. (2008). - Insight into the tectonomagmatic evolution of NW Mexico: Geochronology and petrochemistry of the Miocene volcanic sequences from the Pinacate area (Sonora). - Geol. Soc. Amer. Bull., 120, 5-6, 691-708.

White M.W., Albarède F. \& Telouk F. (2000). - High-precision analysis of $\mathrm{Pb}$ isotopic ratios by multi-collector ICP-MS. - Chem. Geol., 167, 257-270.

Wilson D.S., Mccrory P.A. \& Stanley R.G. (2005). - Implications of volcanism in coastal California for the Neogene deformation history of western North America. - Tectonics, 24, TC3008. doi: 10.1029/2003TC001621.

Zindler A. \& Hart S. (1986). - Chemical geodynamics. - Ann. Rev. Earth Planet. Sci., 14, 493-571. 